Kansas State University Libraries

New Prairie Press

\title{
DEVELOPMENT OF EXPERIMENTS FOR THE HARVESTING AND STORING OF VIDALIA SWEET ONIONS
}

\author{
Ben G. Mullinix \\ Bryan W. Maw \\ Reid L. Torrance
}

Follow this and additional works at: https://newprairiepress.org/agstatconference

Part of the Agriculture Commons, and the Applied Statistics Commons

\section{(c) (1) $\Theta$}

This work is licensed under a Creative Commons Attribution-Noncommercial-No Derivative Works 4.0 License.

\section{Recommended Citation}

Mullinix, Ben G.; Maw, Bryan W.; and Torrance, Reid L. (2001). "DEVELOPMENT OF EXPERIMENTS FOR THE HARVESTING AND STORING OF VIDALIA SWEET ONIONS," Conference on Applied Statistics in Agriculture. https://doi.org/10.4148/2475-7772.1228

This is brought to you for free and open access by the Conferences at New Prairie Press. It has been accepted for inclusion in Conference on Applied Statistics in Agriculture by an authorized administrator of New Prairie Press. For more information, please contact cads@k-state.edu. 


\title{
DEVELOPMENT OF EXPERIMENTS FOR THE HARVESTING AND STORING OF VIDALIA SWEET ONIONS
}

\author{
Ben G. Mullinix ${ }^{1}$, Bryan W. Maw ${ }^{2}$, and Reid L. Torrance ${ }^{3}$ \\ ${ }^{1}$ Ag. Res. Statistician, Experimental Statistics Unit \\ ${ }^{2}$ Research Professor, Biological and Agricultural Engineering Dept. \\ Tifton Campus, Tifton, GA 31793-0748 \\ ${ }^{3}$ Extension Coordinator, Tattnall County, Reidsville, GA \\ College of Agricultural and Environmental Sciences, University of Georgia
}

\begin{abstract}
Sweet onions brought in nearly $\$ 70$ million in 1998. Sweet onions have a soft bulb which makes them susceptible to injury if handled too roughly. Once injured, invasion by pathogens tends to render the bulbs unusable except for quick sale. They were harvested by hand until about ten years ago when efforts were begun to develop a mechanical harvester. Also, at that time, work was underway to develop a way of storing part of the crop so as to extend the market window beyond the traditional 6-8 weeks. Low temperature and low oxygen atmosphere conditions proved to be the most suitable. In 1998 and 1999, sweet onions were hand and machine harvested. They were stored for 30 weeks to determine the practicality of extending the market window. Storability of onions in bulk from the two harvest methods were compared using a mixed model analysis. A mixed model analysis was done on all the research data collected between 1992 and 1998 on curing and storing onions.
\end{abstract}

\subsection{Introduction}

Cultivation of sweet onions has expanded from 400 acres (988 ha) in 1978 valued at $\$ 0.5$ 0.75 million (Smittle and Williamson, 1978), to 6175 acres (15252 ha) in 1988 valued at $\$ 30$ million (Maw and Smittle, 1988), to 12,474 acres (30811 ha) in 1998 valued at $\$ 68.7$ million (Maw and Mullinix, 1999). Onions have been grown since the 30's (Maw and Smittle, 1988), but sweet onions were promoted during the 70's as an alternative crop with high cash value in the east central region of Georgia between Vidalia and Reidsville on the sandy soil of the Ocmulgee, Oconee, and Altamaha rivers (all or part of 20 counties comprise the "Vidalia" Onion area). Most of the sweet onions grown are the 'Granex' variety (Allium cepa L.) (Batal et al., 1994) or have 'Granex' in its parentage.

Sweet onions are direct-seeded between early October through middle of November for harvest the following late April through end of May (Smittle, 1983). They can be transplanted middle of January to middle of February for harvest during the same time frame (Boyhan and Torrance, 1999). However, they can be direct-seeded in January or early February for harvest throughout June (Smittle and Williamson, 1978). Originally, onions were harvested, with infield curing time of 3-8 days, over a 4-6 week period in order to hit various fresh market windows. Maw and Sumner (1998) presented a guide that described how to harvest and cure Vidalia sweet onions.

Onions were originally placed in $50 \mathrm{lb}(23 \mathrm{~kg})$ mesh bags by mixed grade in the packing shed when they were cleaned. More recently, onions have been graded first, then placed in $40 \mathrm{lb}$ $(18 \mathrm{~kg})$ mesh bags by grade (Maw and Sumner, 2000). The grades are Jumbo [ $>3.5$ in $(8.9 \mathrm{~cm})$ diameter], Large [ $>2.5$ to 3.5 in $(6.4-8.9 \mathrm{~cm})]$, Medium [ $>1.5$ to 2.5 in $(3.8-6.4 \mathrm{~cm})]$, and Small [1.5 in $(3.8 \mathrm{~cm})$ or smaller]. Grading onions by size increased the value of the crop by catering to the needs of various customers. Currently, graded sweet onions are placed in 5 or $10 \mathrm{lb}$ 
$(2.3 / 4.5 \mathrm{~kg}) \mathrm{bags} / \mathrm{boxes}$ for direct sale to customers, and pallet bins for storage.

Of concern to onion growers is the high cost of production (Smittle, 1983). Direct-seeded onions cost $\$ 1,869$ per acre $(\$ 4616 / \mathrm{ha})$ from planting through harvesting, while transplanted onions cost $\$ 2,858$ per acre $(\$ 7059 / \mathrm{ha}$ ) (more labor). Smittle (1983) said that marketing 200 to 300 thousand $50-\mathrm{lb}(23 \mathrm{~kg})$ bags did not present a serious problem in the $3-4$ week marketing period in 1975, but marketing the 4-5 million bags in 1983 will present a serious problem if no bags are stored for later marketing. Smittle (1992) discussed with onion growers the feasibility of storing onions in a controlled atmosphere (CA) facility similar to those being used in the apple industry.

\subsection{Previous Experiments}

Onions are grown in beds six feet $(1.82 \mathrm{~m})$ wide with four rows, one foot $(30 \mathrm{~cm})$ apart (Smittle and Williamson, 1978). Approximately 150,000 onion seeds are planted per acre $(370,500 / \mathrm{ha})$. Since germination rarely exceeds $70 \%$, this nets out to be 75,000 to 105,000 plants per acre $(185,000-259,000 / \mathrm{ha})$. Introduction of precision planters that can handle pre-germinated or gel-covered seeds achieved about 80,000 plants per acre $(197,600 / \mathrm{ha})$ in two-inch $(5 \mathrm{~cm})$ staggered pattern along the row. Earlier cultural practices included hand thinning and transplanting to achieve the desired number of plants per foot.

\subsection{Fertilization}

Bed preparation consisted of tilling with a moldboard plow, 8 in. deep, and incorporating fertilizer $(5-10-15,+7 \% \mathrm{~S})$ at $800 \mathrm{lbs} /$ acre $(897 \mathrm{~kg} / \mathrm{ha})$ (Smittle, 1984). Additional fertilizer (as $\mathrm{NH}_{4}-\mathrm{NO}_{3}$ ) was broadcast at 4-week intervals through twenty weeks after planting. Different rates of $\mathrm{N}$ did not result in greater yield of onions. Additional potassium fertilizer (as 0-0-60) was broadcast at 12 weeks after planting (see also Gamiely et al., 1991). Gypsum fertilizer (19\% S) was broadcast at 1.5 and 17.5 weeks after planting. Gypsum effect compared to no gypsum resulted in significantly more larger onions, significantly less decayed bulbs after one month of storage, and no difference in taste panel preference (see Chance and Schmidt, 1995). Bulb bolting (producing a seed head) is a severe problem in growing sweet onions. Severe freezes [below $15^{\circ} \mathrm{F}\left(-9^{\circ} \mathrm{C}\right)$ ] as soon as December, and as late as February; and less severe freezes in March and April have caused bolting. Too much nitrogen followed by a cool period has also caused bolting (Purvis, 1999). The bulb hardens as a result of bolting and the concentration of pyruvic acid (low conc $=$ sweeter taste) increases rapidly. Description of the control of diseases using pesticides can be found in Gay (1998), Sumner (1998; 1999; 2000), Sumner and Gay (1995), and Sumner et al. (1997).

Batal et al. (1994) examined source of nitrogen and differential application rates of nitrogen on sweet onions (see Boyhan et al., 2000). Increased rates of nitrogen resulted in a larger percentage of heavier bulbs (premium marketable grades: Jumbo \& Large) as well as greater total yield for traditional sources of nitrogen fertilizers (see Purvis, 1998). However, at the lower nitrogen rate, total yield did not vary with source of nitrogen and neither did percentage of premium grades by weight. Ammonium nitrate fertilizer did well regardless of the type of split application strategy used during the season. All other nitrogen sources responded well to $1 / 3$ applied in two evenly split amounts (weeks $1 \& 4$ ), and the remaining $2 / 3$ applied in three evenly split amounts (weeks 16, 20 \& 24). All other split combinations produced significantly lower yields. Too much nitrogen early in the season resulted in significantly more rotten bulbs.

Batal (1995) examined combinations of conventional and controlled-release fertilizers on the production of sweet onions, and on grade distribution. There was no significant difference in number of onions harvested. There was a significant difference in number of marketable onions 
harvested, total weight of onions harvested, and weight of marketable onions harvested. Applying no nitrogen fertilizer resulted in no marketable yield. Applying fertilizer only at planting resulted in only $16 \%$ of the onions, by weight, being marketable. Multiple nitrogen applications resulted in 40 to $50 \%$ being marketable. Batal concluded that treatments high in $\mathrm{N}$ and $\mathrm{K}$, applied later in the season, increased bulb weights significantly.

\subsection{Harvesting Sweet Onions}

As the acreage devoted to sweet onions increased over the last two decades, so has the need for farm laborers to harvest the onions. In the 1980's work was begun on an onion harvester. Four basic activities were required when researchers watched the experienced farm laborers harvesting onions. First, the onion had to be wrenched from the soil; second, the onion had to be picked up; third, the roots cut off near the base of the bulb and the top had to be cut off about 1-2 inches above the bulb; and fourth, the onion had to be put in a container. All the cutting actions had to be precise as to not damage the surface of the bulb.

An undercutter attached to the power-takeoff of a tractor was designed (Maw and Smittle, 1986) where the cutter bar would travel just below the soil surface moving back and forth slicing the roots from the bulb. Just behind the cutter bar, was a second bar which would move up and down rapidly over a short distance to pop the bulb out of the soil. The onions would now be laying on top of the ground ready to be harvested.

A potato harvester was reconfigured to harvest onions (Smittle and Maw, 1988). A field planted in four rows per bed at 81,000 plants per acre $(200,000 / \mathrm{ha})$ was test harvested with the machine and with experienced farm laborers. Since the onions were being shuttled up a conveyor belt, they had to be put into a 5-ton $(4.5 \mathrm{Mg})$ wagon. Onions at three maturity stages $(14,52$, and $82 \%$ of tops down) were harvested. Percent marketable bulbs were lower with the mechanical harvester than those harvested by hand after one month of storage. An onion with the top just drooping over is at its maturity peak which is when pyruvic acid content is lowest (correlated with sweet flavor). The low rate of marketable bulbs of the machine-harvested onions led to its being abandoned.

\subsection{Field and Artificial Curing}

Originally, onions were left in the field to cure. That is, the outer one, two, or three skin layers are allowed to dry to protect the bulb from disease invasion (Maw et al., 1993). Onions harvested too early would begin rotting in the field before the curing process was complete (1-4 days of sunshine), while onions harvested too late would begin rotting while still in the ground. Sweet onions, having low levels of pyruvic acid (sweeter taste), are more susceptible to disease invasion since pyruvic acid is a natural defense mechanism in onions. Knowing when to harvest sweet onions became a test of skill. Smittle and Williamson (1978) conducted tests on onions in different stages of tops being erect to tops completely withered. Pyruvic acid content was the lowest when the top (stem) was softening and just beginning to droop. Randle (1998) examined the variation of bulb pungency (onion flavor) within various fields and found it to be highly variable (0.9 to $9.0 \mu$ mols pyruvic acid, ideal 2.5-3.0) (see also Vavrina and Smittle, 1993).

A problem encountered was that not all onions in an area to be harvested was in the same stage of tops down. Maw et al. (1997a,c; 1998c; 1999b) harvested onions at various stages of tops in down position. The onions were artificially cured for 12 to 48 hours. A curing index was developed linked to turgidity of the stem. A value of 1.0 meant the neck was undried (too prone to disease invasion), a value of 2.5 meant stem is drying and bulb skins are crisp, a value of 4.0 meant neck internally dry to near bulb. A value of 5.0 meant neck is completely dry and bends easily. As a result of the curing index, it was determined that both early and late harvested 
onions could be artificially cured. Onions harvested at Early maturity had $0 \%$ of the tops down and $100 \%$ of necks ( 1 inch portion up the stem from the bulb) still hard. Onions harvested at Optimum maturity had $7 \%$ of the tops down. Onions harvested at Late maturity had $100 \%$ of the tops down with $100 \%$ soft necks. These maturity stages were about two weeks apart in an optimal growing year, but varied widely based on climate conditions during the two weeks before early harvesting normally begins through when late harvesting normally ends. Cooler conditions slows onion readiness, while hot, dry conditions speeds onion ripening.

Maw (1993) designed an artificial curing apparatus making use of a 5-ton (4.5 Mg) wagon where heated air $\left[99^{\circ} \mathrm{F}\left(37^{\circ} \mathrm{C}\right)\right]$ was forced up through the bottom of the wagon with a steel mesh floor (Maw et al., 1997b) for 12, 24, or 48 hours. This was currently being used for drying peanuts for storage. Putting the onions in the large wagon caused the first onions to be damaged when hitting the metal surfaces, while succeeding onions caused more damage. The depth of onions proved to be too much to try to cure them effectively and efficiently. A smaller drying stack [ $1 \times 1 \times 4 \mathrm{ft}(30 \times 30 \times 120 \mathrm{~cm})$, (Maw, 1995)] was designed the following year which showed that onions could be cured artificially. Eight of these stacks were placed over a plenum where heated air $\left[99^{\circ} \mathrm{F}\left(37^{\circ} \mathrm{C}\right)\right]$ was forced by a large fan up through the onions. The curing index showed that the earliest harvested onions generally failed to be completely cured even when the equipment ran for 48 hours. Storability was found to be correlated with curing index.

\subsection{Damage from Harvesting and Post-Harvest Handling}

Sweet onions are also softer onions and are subject to bruising and damage (Hung et al., 1993; 1994; 1995; Maw et al., 1989; 1996; Purvis and Hakim, 1999a; Tollner et al., 1995). Because pyruvic acid is lower (sweeter taste), sweet onions are susceptible to disease invasion (Gitaitis, 1995; 1998; 1999; et al., 1991; Langston, 1999). Therefore, it is most important not to cause a break anywhere on the surface of the sweet onion. However, sweet onions must be harvested mechanically to keep its price competitive with hard onions. Hand harvest is too expensive, but several studies have confirmed that rate of damage is significantly less.

Hung et al. (1993) sampled 80 medium-sized onions from each of four harvest maturities and randomly impacted 20 onion bulbs with one of four levels of force $[0,1.6,5.9,24$ in $(=$ free fall drop) $(0,4,1561 \mathrm{~cm})]$. One quarter of the onions were stored for $1,2,3$, or 4 months at $68^{\circ}$ F. Even though harvest maturity or time in storage did not influence bruise damage rating, level of impact force was significantly related to damage rating. Over mature onions had a higher number of rings damaged which was surprising since they cure more easily and possess less moisture. Rotting remained low for the first three months of storage, but increased dramatically during the fourth month. Hung et al. (1994) sampled 80 medium-sized onions from each of three harvest maturities and randomly impacted 20 onion bulbs with four levels of force $[0,5.9,24,34$ in $(=$ free fall drop) $(0,1561,87 \mathrm{~cm})]$. One quarter of the onions were stored for $1,2,3$, or 4 months at $68^{\circ} \mathrm{F}\left(20^{\circ} \mathrm{C}\right)$. Optimum harvest maturity onions were the firmest, and early maturity onions were the least firm. However, outer surface damage was highest on late maturity (over mature) onions. Bruise damage increased with storage time but not with level of impact force. However, internal damage was greatest with early harvested (immature) onions. Ratio of the smallest and largest diameters put the shape of the onions (0.62) to be between that of an egg (0.5) and a sphere (1.0).

Tollner et al. (1995) used nondestructive methods to classify onions as either potentially good or bad by using a tomographic (CT) scanner. They reported a success rate of $76 \%$ for early and late maturity harvested onions which was significantly lower than the success rate for optimum maturity harvested onions. First attempts tended to over predict bad onions (38\%) in the early harvest where $63 \%$ of them were good after storage, compared with $24 \%$ bad where $58 \%$ were good for the late maturity. Hung et al. (1996) used a puncture probe (3.2 $\mathrm{mm} \mathrm{dia}$.) to 
measure force on onions just after they were cured (fresh) and after three months of controlled atmosphere (CA) $\left[3 \% \mathrm{O}_{2}, 5 \% \mathrm{CO}_{2}, 92 \% \mathrm{~N}_{2}\right.$, and $\left.34^{\circ} \mathrm{F}\left(1^{\circ} \mathrm{C}\right)\right]$ and cold $\left[\mathrm{CS}, 34^{\circ} \mathrm{F}\left(1^{\circ} \mathrm{C}\right)\right]$ storage. It required less force to puncture through the first and second ring of onions from cold storage (CS) than from CA. Color rating and axial shape was the same for all three treatments. However, occurrences of surface damage were significantly higher for stored than for fresh onions. X-ray imaging and computer vision were used to detect defects in onions (Maw et al., 1995; Shahin et al., 1999; Tollner and Shahin, 1998; 2000). Beginning with a sample of four hundred bulbs (in 1998), half were randomly chosen to be inoculated to increase decay. Half of each treatment was stored at room temperature $\left[68^{\circ} \mathrm{F}\left(20^{\circ} \mathrm{C}\right)\right.$ at $65 \% \mathrm{RH}$, to enhance development of decay] and the remainder in $\mathrm{CS}\left[43^{\circ} \mathrm{F}\left(6^{\circ} \mathrm{C}\right)\right.$ at $\left.85 \% \mathrm{RH}\right]$. Every two weeks, onions were scanned with one onion in each treatment combination being sliced in half for visual inspection. When an onion was found to be rotten, it was removed from the study. Based on the matching of visual and $x$-ray images, about $90 \%$ of the onions were successfully classified. Most of the misses were good onions (about 10\%) showing defects when there were no visual defects. In 1999, the 1998 images were processed on computer using a standard image to compare against by using selected points for comparison tests. Analysis of the test points using Bayesian classifer methodology showed that approximately $90 \%$ of the images examined were found to be damage and/or defect free. This agreed with the visual comparisons made a year earlier. Based on Bayesian classifer tests, only $80 \%$ were found to be good onions. All of the defective onions were found but only two-thirds of the false positives from a year ago were found. In 2000, a trigonometric transform (mathematical function) algorithm was tested on the images obtained from the 1998 sample of onions. A sample of apples was also compared to check on the compatibility of the two crops to respond to the same x-ray imaging. About $90 \%$ of the processed images of both crops were correctly identified. Nearly all of the false positives $(17 \%$ classified as rotted from previous year) were found to be normal by this new processing system.

\section{$\underline{2.5 \text { Long-term Storage of Sweet Onions }}$}

Smittle and Williamson (1978) began work on the feasibility of storing sweet onions for future market windows that were not currently available, since this was being done with hard onions. They discovered that reducing the $\mathrm{O}_{2}(20 \%$ down to $3 \%)$ and increasing the $\mathrm{CO}_{2}(<1 \%$ up to $5 \%)$ and $\mathrm{N}_{2}(79 \%$ up to $92 \%)$ in the storage atmosphere, hence controlled atmosphere (CA), helped reduce spoilage. Onions harvested at the optimum maturity having the lowest pungency also proved to be the best for storage (Smittle et al., 1979; Smittle, 1988; 1989a,b; $1990 ; 1991 \mathrm{a}, \mathrm{b}, \mathrm{c} ; 1994)$. No storage treatment examined maintained pungency level. Two of 14 atmosphere treatments experienced less than 0.5 unit increase, while four experienced over 2.0 unit increase in pungency level. Various temperatures were also examined and storage at $34^{\circ} \mathrm{F}$ $\left(1^{\circ} \mathrm{C}\right)$ was found to be the best. Earlier tests at $40^{\circ} \mathrm{F}\left(4^{\circ} \mathrm{C}\right)$ saw up to $90 \%$ of the bulbs showing interior decay. However, it was soon determined that a huge initial investment would be required to have such a facility that would hold a substantial portion of the harvested onions until new market windows opened up (Maw, 1995). Maw described five market windows: Fresh (immediate), early season (minimal, 1-2 weeks), middle season (moderate, 2-4 weeks), late season (moderately long, 5-6 weeks), and CA storage (long, 7-30 weeks). The longer to store onions, the more it would cost to hold onions in storage.

Maw (1993; 1994; 1995; and Lahue, 1996; et al., 1997b) and Mullinix et al. (1996b) designed experiments using air conditioned air (ACL) that maintained temperature $\left[70-80^{\circ} \mathrm{F}(21\right.$ $\left.\left.27^{\circ} \mathrm{C}\right)\right]$ and humidity $(70 \% \mathrm{RH})$, and air conditioned cooled air $(\mathrm{ACH})\left[<65^{\circ} \mathrm{F}\left(18^{\circ} \mathrm{C}\right)\right]$ with lower humidity $(30-50 \% \mathrm{RH})$. Onions were stored in bags for thirty weeks. Rotten onions were removed from each bag every two weeks. In 1992, onions were harvested at five maturity stages (over 4 weeks) to determine how maturity level would affect storability. Since 1992, only the 
first (Early), third (Optimum), and fifth (Late) harvest maturities have been used.

Generally, onions harvested at optimum or up to 10 days before did well during the first 10 weeks with better than $95 \%$ still present. However, by week 14 only $60 \%$ of the earliest harvested onions were still present, while $75 \%$ of the optimum harvested onions were still present. Onions harvested later tended to steadily disappear until less than $70 \%$ were present. By week 10, 95\% of the onions were still good for all curing times. Curing duration of 12 or 24 hours declined to $65 \%$ of the onions still good. Good onions with curing duration of 48 hours fell below $75 \%$ by week 14 . In 1993, only three harvest maturities were used (Early, 5/3; Optimum, 5/24; Late, 6/3). Each box was constructed from plywood [1 x $1 \times 1 \mathrm{ft}(30 \mathrm{~cm})]$ were used to cure the onions. Eight stacks of four boxes were placed over a plenum where heated air $\left[99^{\circ} \mathrm{F}\left(37^{\circ} \mathrm{C}\right)\right]$ was forced up through the stack. Temperature and humidity sensors measured the outgoing air at the top $\left(94^{\circ} \mathrm{F}\left(34^{\circ} \mathrm{C}\right)\right)$ with \% RH at 43 and 46, incoming and outgoing, resp. Curing durations of $12,24,48$, and 72 hours were used. Ninety percent of the early harvested onions were still good after 16 weeks of storage in the same conditions as described for 1992. Optimum harvested good onions fell below $90 \%$ by week 4 , while late harvested good onions fell below $90 \%$ by week 2 . Cure duration of 12 hours was the worst at maintaining good onions at any harvest maturity, while those cured for 72 hours were the best.

In 1994, only three harvest maturities were used (Early, 4/27; Optimum, 5/5; Late, 5/18). The same boxes were used as in 1993. Curing durations of $24,48,72$, and 96 hours were used. Ninety percent of the early harvested onions were good through week 6 . While optimum and late maturities reached $90 \%$ good by weeks 4 and 2, resp. Even though more onions reached week 30 than had the previous year, cost of building an on-farm storage facility could not be justified. It was discovered that the smaller graded onions tended to have better storability. Jumbo onions fell below $90 \%$ good by week 2 and steadily declined to zero by week 30 . All other grades fell below $90 \%$ good onions by week 4 . Large, medium and small good onions declined to about 15,25 and $40 \%$ remaining, respectively.

In 1995, three harvest maturities were used (Early, 4/20; Optimum, 5/9; Late, 5/23). The same boxes from 1993 \& 1994 were used. Curing durations of 24, 48, 72, and 96 hours were used. Four environmental storage treatments were used. The same two air conditioned storages as in previous two years called $\mathrm{ACH}$ and $\mathrm{ACL}$. CS $\left[34^{\circ} \mathrm{F}\left(1^{\circ} \mathrm{C}\right)\right]$ and controlled atmosphere (CA) $\left(3 \% \mathrm{O}_{2}, 5 \% \mathrm{CO}_{2}, 92 \% \mathrm{~N}_{2}\right.$, and $\left.34^{\circ} \mathrm{F}\left(1^{\circ} \mathrm{C}\right)\right)$ were added since the new Onion Research Facility was ready to use. After 10 weeks of storage, a fire made the new facility unuseable. The CA onions were transferred to the CS facility. After another 6 weeks of storage, the CS facility was no longer available for use. The CS onions were placed in the ACL storage facility. Since the CA storage facility required being sealed, onion measurements were limited to every four or six weeks. All other onions were examined every two weeks. Two sets of onions were maintained. The first set of onions were the bagged onions. Each bag was examined for the count of rotten onions which were weighed. The remaining good onions were counted and weighed. The second set of onions were individually weighed and their grade was redetermined. All data collected were recorded for analysis at the end of the storage period which was set at thirty weeks. Over ninety percent of the onions placed into CS and CA storage were still good after eight weeks. Once they were removed and placed in ACL storage, the percentage good onions quickly caught up with the ACL onions. Less than $10 \%$ of the onions were still good after 30 weeks. Percent weight loss per week exceeded $1.25 \%$ for ACH stored onions, exceeded $1.1 \%$ for ACL stored onions, exceeded $1 \%$ for CS onions, and was less that $1 \%$ for CA stored onions. Precision was twice as high for $\mathrm{ACH}, \mathrm{ACL}$, and $\mathrm{CS}$ as it was for CA stored onions. Curing indices did not exceed 4.0 for early harvested onions even though they were cured for 96 hours; were barely over 4.0 for optimum harvested onions even after 96 hours; and were between 4.0 and 5.0 for late harvested onions even after 72 hours of curing. 


\subsection{Designing an Experiment Based on Previous Experimental Results}

Three different research directions, beginning in 1996, were determined: 1) Continuing the development of a mechanical harvester since laborer costs were skyrocketing and the number of acres planted in onions were increasing as well. 2) Improved efficiency in curing onions in bulk amounts was beginning to show that it could work in a farm setting. 3) Use of a farm-site cold storage facility and a newly built controlled atmosphere storage facility to demonstrate that onions could be stored for post-season consumer use windows. Increased funding from the onion growers' committee with matching state funds provided an impetus to embark on the three directions concurrently.

\section{$\underline{3.1 \text { Mechanical Harvesting of Onions }}$}

A single-row harvester (Maw et al., 1998a,b; 2001a) was designed to undercut the onion (root removal), a second bar would pop the onion out of the ground (hopefully in upright stance), and two rubber disks would gather the onion by the top passing it along to where two rubber belts would grab the onion by the top. During the trip to the bagger facility located at the rear of the harvester, a knife would cut the top off allowing the onion to fall onto a padded conveyor belt with cleats to move the onion to the bag. After many trial and error attempts, the final design of the harvester emerged which speeded up the harvesting process. However, in a timed trial, experienced farm laborers were able to completely harvest a measured bed of onions faster than the harvester. There was about as many damaged onions percentage wise between the two methods. Further improvements using a video camera to study the actual machine operation yielded many clues which could reduce rate of damaged onions by the machine. At a normal pace, the farm laborers could achieve an extremely low percentage of damaged onions. Rate of damaged onions decreased with time of day and with maturity of onions.

A four-row hard onion harvester (Maw et al., 1998d; 1999a,b; 2001b) was tested on onions which had been undercut. Adjustments in the mechanical action of the moving parts, particularly padding of metal parts, significantly reduced damage to onions. Placing a layer of harvested cotton on the floor of the catching bin further reduced onion damage. Designing an adjustable conveyor belt and using a 1-ton $(907 \mathrm{~kg}$ ) wagon reduced rate of bruising and damage of the onions. Other cultivars [e.g., 'Pegasus' and 'Equanex' (Maw et al., 1998d)] have been tested to determine their ability to withstand rougher handling during mechanical harvesting.

Maw et al. (2001a) continued to make improvements on the one-row harvester. Six rows were harvested. Two each from three 4-row beds. The rows were measured to be $378 \mathrm{ft}(115 \mathrm{~m})$ in length. The operator could travel at a moderate speed of $1.43 \mathrm{mph}(2.3 \mathrm{~km} / \mathrm{h})$ or a fast speed of $2.15 \mathrm{mph}(3.4 \mathrm{~km} / \mathrm{h})$. More missed onions occurred in the morning when the onion stems were still wet. That is when greater damage occurred. Damaged onions amounted to $22 \%$ for the moderate and $13 \%$ for the fast speed. Onions that did not make it to the bin on the rear of the harvester amounted to $13 \%$ for the moderate with $12 \%$ of these damaged; and $9 \%$ did not make it to the bin for the fast speed with $18 \%$ of these damaged. Based on the results, the one-row harvester would be able to cover $1.0 \mathrm{acres} / \mathrm{hr}$ at the moderate speed, and cover $1.5 \mathrm{acres} / \mathrm{hr}$ for the fast speed. The type of damage occurring to the onions was determined by visual inspection. A total of 1063 damaged onions were examined, 107 onions were rejected since 47 were not damaged and the others were damaged but not by the harvester during normal operation (damaged when the harvester malfunctioned). Of the 956 that were damaged: 326 were small grade (34.1\%), 308 were medium grade $(32.2 \%), 228$ were large grade $(23.8 \%)$, and 94 were jumbo grade $(9.9 \%)$; and 194 were sheared $(20.3 \%$, front undercutter assembly), 247 were nicked $(25.8 \%$, conveyor assembly), and 515 were gouged (53.9\%, front gathering assembly). Larger graded onions tended to be gouged, while smaller graded onions tended to be nicked, and 
small grade onions tended to be sheared. As a test, all damaged onions were cured for 96 hours. Each onion was judged either marketable or unuseable. By weight, $56.2 \%$ of the onions were found to be marketable because the injury failed to go beyond the first or second leaf layer.

In 1997, two onion cultivars ('Equanex' and 'Pegasus') were either hand harvested (HH), machine harvested with no tops removed (MU), or machine harvested with tops removed (MT) (Maw et al., 2001b). They were cured in the $1 \times 1 \times 4 \mathrm{ft}(30 \times 30 \times 120 \mathrm{~cm})$ curing facility for 24 hours. They were put as mixed grades in cardboard crates [ $20 \times 10 \times 10$ in $(51 \times 25 \times 25 \mathrm{~cm})]$. They were placed in an air conditioned cooled air storage facility. Figure 1 shows the results of storage longevity. Nearly all of the mixed grade onions had rotted by week 30 . The MT onions disappeared the fastest, while 'Pegasus'-HH disappeared at the slowest rate through at least week 18.

In 1998, two onion cultivars ('Savannah Sweets' and 'Sweet Vidalia') were either hand harvested $(\mathrm{HH})$, machine harvested with no tops removed (MU), or machine harvested with tops removed (MT) (Maw et al., 2001b). They were cured and stored the same as described for the 1997 onions. After 12 weeks, 53\% of the Savannah sweet onions were good (Figure 2), while only $7.5 \%$ of the Vidalia sweet onions were good. Savannah sweet onions, which were machine harvested, had $52.5 \%$ of the onions were still good; but only $5 \%$ of Vidalia sweet onions that were machine harvested were still good. Savannah sweet onions, which were hand harvested, had $55 \%$ of the onions were still good; but only $11 \%$ of Vidalia sweet onions that were hand harvested were still good.

In 1999, two cultivars ('Nikita' and 'Sweet Vidalia') were harvested with a four-row (one bed) harvester with a topper attachment (MT) or without the topper attachment (MU), or hand harvested (HH) (Maw et al., 2000b; 2001b). They were put in plastic bins $(0.5$ ton $(454 \mathrm{~kg})$ capacity) for curing. They were cured just long enough (curing index $=5$ ). They were moved to $\mathrm{CA}$ storage for 21 weeks. Figure 3 shows the results of storage longevity. The two $\mathrm{HH}$ treatments disappeared at the slowest rate, while "Nikita'-MU disappeared at the fastest rate. Vidalia sweet onions showed little difference in rate of disappearance among the three harvest methods. Even though 'Nikita' was found to be a firmer sweet onion from the laser puff experiment to be described later, it evidently did not respond well to being machine harvested.

\subsection{Interaction between Harvest Maturity and Duration of Curing}

Maw et al. (1998c) described an experiment where onions were harvested at three harvest maturities and artificially cured from 24 to 96 hours which included a control (no forced air). It was concluded from the storage phase of the study that early harvested onions benefitted from the extended curing hours, optimally harvested onions were not harmed by over-curing, and while over mature onions showed signs of being harmed by 96 hours of curing (see Purvis and Hakim, 1999b). In 1994, the Vidalia Onion Marketing Committee matched seed funds from the legislature for the Vidalia Onion Research Facility where controlled atmosphere (CA) and cold storage (CS) experiments could be conducted. The facility was not completed in time for the next year's onion harvest. A fire damaged the facility preventing its use the following year. In 1996, the first CA and CS studies could be conducted. However, an area disease outbreak caused most of the onions to rot within 10 to 18 weeks of storage. In 1997, CA and CS studies showed that onions could be stored from May until November/December when a major market window became available for holiday cooking. In 1998, onions in CA lasted into January of the following year. Since then, onions stored in plastic bins (Maw and Sumner, 2000) for storage allowed air to flow throughout were available for experiments in the following February.

Sweet onions will not store very long if curing is incomplete (Maw et al., 2000c). Curing is absolutely essential if the sweet onion is to be protected from invasion by various disease pathogens. The outer skin layers should dry, the neck stem area should seal, and the base where 
the roots attach should be intact. For disease to survive, it requires moisture on the inside of the onion to be replenished. Curing done properly denies this moisture replenishment. Even after removal from storage, evidence of continued curing can be observed (Mullinix et al., 1996a; 1997). During the storage process, an onion can rot if the skin is broken allowing internal moisture level to change, the center leaves and root crown begin to sprout, or disease initiates rotting (pathogen probably invaded before harvest).

Non-destructive tests were conducted to determine if impact damage can eventually lead to the bulb rotting (Tollner et al., 1995). Impacting on any metallic or equally hard surface resulted in some type of internal and/or external bruising. However, when onions were dropped onto other onions, as would occur during harvesting by dropping onions off the conveyor belt into a trailer, incidence of external bruising was minimal and internal bruising was nonexistent. Immature onions, those likely to be harvested early, were more subject to evidence of bruising than were more mature onions. Purvis and Torrance (1999) used an instrumented sphere (IS) to determine the amount of impact an onion can withstand before showing evidence of external damage. Since the IS weighs as much as a jumbo onion [310 $\mathrm{g}(10.9 \mathrm{oz})]$, it is ideal to use in drop tests with an onion. The IS was run through a mechanical harvester and averaged about 130 $\mathrm{g}$ of acceleration from five runs. The drop from the harvester to the trailer averaged $113 \mathrm{~g}$ of acceleration. During the handling phase, the forklift lifting the bin of $1000 \mathrm{lbs}(454 \mathrm{~kg})$ of onions produced an acceleration of $219 \mathrm{~g}$. The packing line where onions have been culled and graded produced an acceleration of $113 \mathrm{~g}$ when storage bins were being filled.

Maw et al. (2000a; 2001c) used a laser puff machine where a laser beam measures the amount of deflection when a thin jet of pressurized air hits the surface of the onion. Differences between varieties of sweet onions were observed. Three of the varieties which are currently being used in field research are 'Granex 33' and 'Sweet Vidalia' were the softest, while 'Nikita' was the firmest. Thirteen varieties were evaluated in 2000 ('Granex Y33' was included). 'IPA-3' was the firmest, 'Granex Y33' was not significantly different; while 'DPS 1039' was the softest.

Maw and Sumner (1999) cooled onions that were removed from the curing bins before they were placed in cold (CS) or controlled atmosphere (CA) storage. This was done to prevent overloading of these systems. It took about eight hours to reduce the temperature from $>98^{\circ} \mathrm{F}$ to $65^{\circ} \mathrm{F}\left(>37^{\circ} \mathrm{C}-18^{\circ} \mathrm{C}\right)$.

The discovery that onions placed in a four foot column for curing with heated air were not being completely cured lead Maw et al. (2000c) to study the characteristics of the air exiting from the top of the column. The problem was that onions near the bottom were showing signs of being over-cured, while those at the top were under-cured. Air flow measurement devices were obtained to determine the amount of air pressure drop that was being experienced in this column. Resistence figures had been established for other crops (i.e., corn, wheat and peanuts) that are routinely dried before being taken to market. Since the four foot column was assembled in one foot sections, the pressure drop was measured across each foot section as the column was assembled. Two additional one foot sections were added to complete the six foot column. At each one foot section, nine different fan speeds $(10,15, \ldots, 50 \mathrm{hz})$ where used to produce a range of volumetric airflows from 8520 to $11300 \mathrm{ft}^{3} \mathrm{~min}^{-1}\left(0.14-18.5 \mathrm{~m}^{3} \mathrm{~min}^{-1}\right)$. Once the six columns had been measured, measurements began with the top section, while measurements continued as each section was removed. A graph of the results on log-log paper produced a straight line with a slope greater than that for bell peppers or potatoes, while comparable to that produced by rice. The reason for this is that onions have a smooth exterior which becomes smoother as curing takes place. Potatoes have a rougher surface, while bell peppers with smooth surface are highly irregular in shape. Rice has an extremely smooth surface.

The following year, plywood was placed around the pallet bins [ $45 \times 44 \times 35$ in $(114 \times 113$ $\mathrm{x} 88 \mathrm{~cm}$ )] and joints were sealed (Maw, 2001). The same procedure was followed as before. After each section was assembled, nine airflow measurements were made. A total of six sections 
were stacked using a forklift. The graphed results were approximately the same. It had been suggested that the pressure drop phenomenon was the same regardless of area varying only depending on the height over which the drop is measured. Jumbo, Large, and Medium grade onions tended to behave similarly to mixed grade onions. However, Small grade onions tended to behave differently since they can pack more tightly in a given volume.

\section{$\underline{3.3 \text { Long-term Storage using Cold Storage and Controlled Atmosphere }}$}

Research plans to begin using the Vidalia Onion Research Facility in 1995 were abruptly ended when a fire partially destroyed the facility. Repairs were not finished in time to be able use it for research when onions were harvested in May and June of 1996. The onion harvesting year of 1997 was the first time onions could be stored in the controlled atmosphere (CA) and cold storage (CS) facilities within this building. Results were extremely promising in 1997. The research was repeated again in 1998. Onions were direct-seeded in latter half of October, 1997 using a Stanhay precision planter. Nutrition requirements followed the recommendations of the Cooperative Extension Service. Early maturity onions were harvested on April 23 and curing began on April 27 (Mullinix et al., 1999). Optimum maturity onions were harvested on May 14 and curing began on May 18. Late maturity onions were harvested on May 26 and curing began on May 30. Five curing treatments were used. Onions were cured with no added heated air (0) for 96 hours, and onions were cured using heated air $\left(99^{\circ} \mathrm{F}\right)$ for $24,48,72$, and 96 hours with the balance of time receiving no added heated air for the 96 hour curing study. The stack where curing took place were four boxes $[1 \times 1 \times 1 \mathrm{ft}(30 \times 30 \times 30 \mathrm{~cm})]$ open at the top and bottom with plastic mesh fabric attached across the bottom to hold the onions in place. Once the heated air was turned off to a stack, the bottom and top of the four foot stack were closed. Onions were held in cold storage until all three maturities were cured. One half of the onions at random went into the CA storage facility which was then sealed. The other half remained in cold storage. For the onions in CS, bags were inspected every two weeks for rotten or unusable onions which were removed, weighed and count by grade were recorded; and the remaining good onions were weighed and recorded. For the onions in CA, this was done every four weeks.

Nearly a third of the onions by count were remaining after thirty weeks of storage. Figure 4 shows the results for jumbo grade onions for duration of curing (A), depth of curing (B), and harvest maturity $(\mathrm{C})$. There was no interaction among storage, duration of curing and longevity of storage, or among storage, depth of curing and longevity of storage. Harvest maturity did interact with CS to a greater extent than with CA. However, late harvested onions did much better in CS $(60 \%)$ than in CA $(40 \%)$. Figure 5 shows the results for large grade onions for duration of curing (A), depth of curing (B), and harvest maturity (C). There was no interaction among storage, duration of curing and longevity of storage, or among storage, depth of curing and longevity of storage. Harvest maturity did interact with CS to a greater extent than with CA. However, late harvested onions did much better in CS (70\%) than in CA (50\%). Figure 6 shows the results for medium grade onions for duration of curing (A), depth of curing (B), and harvest maturity $(\mathrm{C})$. There was no interaction among storage, duration of curing and longevity of storage, or among storage, depth of curing and longevity of storage. Harvest maturity did interact with CS to a greater extent than with CA. However, late harvested onions did much better in CS (70\%) than in CA (40\%). Figure 7 shows the results for small grade onions for duration of curing (A), depth of curing (B), and harvest maturity (C). There was no interaction among storage, duration of curing and longevity of storage, or among storage, depth of curing and longevity of storage. Harvest maturity did interact with CS to a greater extent than with CA. However, late harvested onions did much better in CS (60\%) than in CA (30\%). Figure 8 shows the results for mixed grade onions for duration of curing (A), depth of curing (B), and harvest maturity $(\mathrm{C})$. There was no interaction among storage, duration of curing and longevity of 
storage, or among storage, depth of curing and longevity of storage. Harvest maturity did interact with CS to a greater extent than with CA. However, late harvested onions did much better in CS $(70 \%)$ than in CA $(40 \%)$.

\subsection{Analysis of Seven Years on Onion Research Data}

Data collected over the seven years (1992-1998) on duration of cure and storage environment was found to be too big to be analyzed on the existing computer equipment available to the authors. Means for percent good onions remaining by harvest maturity, duration of cure, or storage environment by duration of storage by year for each grade and grades mixed together were determined. The experimental model was year as the main plot, harvest maturity, curing duration or storage environment was the first split, and storage duration (measured in 2 week intervals) was the second split. Years were considered as a random effect.

Figure 9 shows that harvest maturity $(4.7 \%)$ had little effect on the decline in percent good onions remaining except for the small graded onions. As grade size of the onions became smaller, the percent remaining steadily increased from near zero for the jumbo grade to more than five percent remaining for the small grade. The ANOVA table shows the year effect was the second greatest effect present $(22.7 \%)$, while duration of storage was the greatest effect $(65.3 \%)$.

Figure 10 shows that duration of cure $(0 \%)$ had no effect on the decline in percent good onions remaining except for the small graded onions. As grade size of the onions became smaller, the percent remaining steadily increased from near zero for the jumbo grade to more than ten percent remaining for the small grade. The ANOVA table shows the year effect was the second greatest effect present $(33.5 \%)$, while duration of storage was the greatest effect $(59.2 \%)$.

Figure 11 shows that storage environment $(7.5 \%)$ had some effect on the decline in percent good onions remaining. Controlled atmosphere storage (CA) averaged over twenty percent of the onions remaining regardless of grade. Cold storage (CS) performed slightly lower that did CA until week twenty six. The equipment failed at the storage facility one year but was not detected until the week 28 measurement time. The ANOVA table shows the year effect was the second greatest effect present (33.3\%), while duration of storage was the greatest effect $(53.2 \%)$.

Since onions have been present after 30 weeks in both CA and CS in sufficient quantities from the 1997 and 1998 harvests, these two storage environments have been a qualified success. Premium prices received for onions held in storage until the December market have prompted some onion growers to invest in CA and/or CS facilities.

During the seven years, the authors became aware that over half of the larger onions changed grade due to shrinkage (process of steadily losing moisture across the cured outer leaves). The examination of the onions set aside for detailed measurements, individual onion data, revealed that these onions changed from the grade assigned when they were harvested till the grade assigned when they went to market. Only about ten percent of the onions changed grade from being cured (deliberate removal of moisture). Of course, more grade changes were found when onions were cured for longer durations. The individual onion data was divided by grade and duration of cure from which means and standard deviations were found. Figure 12 shows from a predictive perspective, the probability that a jumbo grade onion will change grade as a result of different curing durations. A jumbo onion weighing $340 \mathrm{~g}$ before curing has about $13 \%$ probability of becoming a large graded onion if it loses $80 \mathrm{~g}$ of its weight. This compares with a jumbo onion [ $320 \mathrm{~g}$ (lost $20 \mathrm{~g}$ during curing)] which has been cured for 96 hours has almost a $20 \%$ probability of becoming a large graded onion if it loses only $55 \mathrm{~g}$ of its weight.

Figure 13 shows from a predictive perspective, the probability that a large grade onion will change grade as a result of different curing durations. A large onion weighing $240 \mathrm{~g}$ before curing has about $12 \%$ probability of becoming a medium graded onion if it loses $55 \mathrm{~g}$ of its weight. This compares with a large onion [210 g (lost $30 \mathrm{~g}$ during curing)] which has been cured 
for 96 hours has almost $18 \%$ probability of becoming a medium graded onion if it loses only 30 $\mathrm{g}$ of its weight.

Figure 14 shows from a predictive perspective, the probability that a medium grade onion will change grade as a result of different curing durations. A medium onion weighing $153 \mathrm{~g}$ before curing has about $10 \%$ probability of becoming a small graded onion if it loses $34 \mathrm{~g}$ of its weight. This compares with a medium onion [142 g (lost $10 \mathrm{~g}$ during curing)] which has been cured for 96 hours has almost 13\% probability of becoming a small graded onion if it loses only $30 \mathrm{~g}$ of its weight.

\subsection{Summary}

Over the past 25-30 years, the cash value of sweet onions in the Vidalia, Georgia area has increased to be worth more than $\$ 70$ million. Almost 20,000 acres of marginal crop land are used to produce the sweet onions known all over the southeastern U.S. Figuring out the nutritional needs of the sweet onion was accomplished within the first fifteen years. What has been more difficult was to store part of the crop for later sale and thus extend the market window for sweet onions beyond the traditional May-June market window. At a huge investment, cold storage and controlled atmosphere storage facilities have been built which has increased the value of the crop. Work in earnest was begun in 1992 on uniformly curing sweet onions in an artificial manner rather than curing onions in the field. Early harvested onions through experiments required at least 72 to 96 hours of heated forced air up through the onions to effect the curing. Optimally harvested onions required 48 to 72 hours, while late harvested onions required 24 to 48 hours. During the years of experimenting (1992-1998), it was discovered that only two times by waiting until the late harvest was there more premium (jumbo \& large) grade onions over the optimum harvest time. Over these seven to nine years (1992-2000), other experiments were run to examine how the curing actually takes place, damage done to onions by handling and curing, and quality of the onions once they were stored for up to 30 weeks. In the process of solving various problems, much has been learned and passed along to the onion growers who saw their collective research funds return dividends many times over so that growing onions is a profitable endeavor. 


\section{References}

Batal, K. M., 1995. Effects of controlled release-conventional fertilizer combinations on yield and leaf tissue elemental composition of sweet onion. 1994 Georgia Onion Research-Extension Report, Dept RI, UGA-CAES Tifton Campus, Tifton, CREP 3-95:2-9.

Batal, K. M., Bondari, K., Granberry, D. M. and Mullinix, B. G., 1994. Effects of source, rate, and frequency of $\mathrm{N}$ application on yield, marketable grades and rot incidence of sweet onion (Allium cepa L. cv. Granex-33). J. Horticultural Science 69:1043-1051.

Boyhan, G., Torrance, R., 1999. Plant bed fertility in Vidalia onions. 1998 Georgia Onion ResearchExtension Report, Dept ECT, UGA-CAES Tifton Campus, Tifton, CREP 3-99:4-10.

Boyhan, G. E., Torrance, R. L. and Langston, D. B., 2000. Evaluation of nitrogen rates in Vidalia onion production. 1999 Georgia Onion Research-Extension Report, Dept ECT, UGA-CAES Tifton Campus, Tifton, CREP 3-2000:1-2.

Chance, W., Schnidt, N., 1995. Status of sulfur nutrition of Vidalia onions in Georgia. 1994 Georgia Onion Research-Extension Report, Dept RI, UGA-CAES Tifton Campus, Tifton, CREP 3-95:10-12.

Gamiely, S., Randle, W. M., Mills, H. A., Smittle, D. A. and Banna, G. I., 1991. Onion plant growth, bulb quality, and Water uptake following ammonium and nitrate nutrition. HortScience 26:1061-1063.

Gay, J. D., 1998. Botrytis neck rot management in Vidalia onions. 1996-97 Georgia Onion ResearchExtension Report, Dept ECT, UGA-CAES Tifton Campus, Tifton, CREP 3-98:3.

Gitaitis, R., 1995. Research of Vidalia onion bacterial diseases for the 1994 season. 1994 Georgia Onion Research-Extension Report, Dept RI, UGA-CAES Tifton Campus, Tifton, CREP 3-95:13-15.

Gitaitis, R., 1998. Bacterial diseases on Vidalia onions, 1996-1997. 1996-97 Georgia Onion ResearchExtension Report, Dept ECT, UGA-CAES Tifton Campus, Tifton, CREP 3-98:4-13.

Gitaitis, R., 1999. Bacteriology - 1998. 1998 Georgia Onion Research-Extension Report, Dept ECT, UGA-CAES Tifton Campus, Tifton, CREP 3-99:11-14.

Gitaitis, R. D., Baird, R. E., Beaver, R. W., Sumner, D. R., Gay, J. D. and Smittle, D. A., 1991. Bacterial blight of sweet onion caused by Pseudomonas viridiflava in Vidalia, Georgia. Plant Disease 75:11801182.

Hung, Y. C., Tollner, E. W. and Maw, B. W., 1996. Physical properties and quality of Vidalia onions stored under different conditions. 1995 Georgia Onion Research-Extension Report, Dept RI, UGACAES Tifton Campus, Tifton, CREP 3-96:5-7.

Hung, Y. C., Tollner, E. W., Maw, B. W. and Smittle, D. A., 1993. Evaluation of impact damage on Vidalia onions. 1992 Georgia Onion Research-Extension Report, Dept RI, UGA-CAES Tifton Campus, Tifton, CREP 3-93:27-29.

Hung, Y. C., Tollner, E. W., Maw, B. W. and Smittle, D. A., 1994. Effect of impact damage on the quality of stored Vidalia onions. 1993 Georgia Onion Research-Extension Report, Dept RI, UGACAES Tifton Campus, Tifton, CREP 3-94:14-16.

Hung, Y. C., Tollner, E. W., Maw, B. W. and Smittle, D. A., 1995. Physical properties and quality of impact damaged Vidalia onions during storage. 1994 Georgia Onion Research-Extension Report, Dept RI, UGA-CAES Tifton Campus, Tifton, CREP 3-95:16-22.

Langston, D., 1999. 1998-1999 Onion disease situation. 1998 Georgia Onion Research-Extension Report, Dept ECT, UGA-CAES Tifton Campus, Tifton, CREP 3-99:15.

Maw, B. W., 1993. The shelf life of Vidalia onions following harvest. 1992 Georgia Onion ResearchExtension Report, Dept RI, UGA-CAES Tifton Campus, Tifton, CREP 3-93:30-34.

Maw, B. W., 1994. The shelf life of Vidalia onions following harvest. 1993 Georgia Onion ResearchExtension Report, Dept RI, UGA-CAES Tifton Campus, Tifton, CREP 3-94:17-23.

Maw, B. W., 1995. The shelf life of Vidalia onions following harvest. 1994 Georgia Onion ResearchExtension Report, Dept RI, UGA-CAES Tifton Campus, Tifton, CREP 3-95:36-46.

Maw, B. W., 2001. Harvesting into and curing Vidalia onions in plastic pallet bins. 2000 Georgia Onion Research-Extension Report, Dept ECT, UGA-CAES Tifton Campus, Tifton, CREP 3-2001:39-41. 
Maw, B. W., Hung, Y. C., Tollner, E. W. and Smittle, D. A., 1989. Some physical properties of sweet onions. Presented at the 1989 International Summer Meeting (ASAE \& CSAE), June 25-28, Quebec, PQ, Paper No. 89-6007 (15 p), St. Joseph, MI 49085.

Maw, B. W., Hung, Y. C., Tollner, E. W., Smittle, D. A. and Mullinix, B. G., 1995. Detecting impact damage of sweet onions using muriatic acid and x-rays. Applied Engineering in Agriculture 11:823826.

Maw, B. W., Hung, Y. C., Tollner, E. W., Smittle, D. A. and Mullinix, B. G., 1996. Physical and mechanical properties of fresh and stored sweet onions. Trans ASAE 39:633-637.

Maw, B. W., Lahue, S. S., 1996. The shelf life of Vidalia onions following harvest. 1995 Georgia Onion Research-Extension Report, Dept RI, UGA-CAES Tifton Campus, Tifton, CREP 3-96:11-21.

Maw, B., Mullinix, B., 1999. Grade and weight distribution of sweet onions harvested at three harvest maturities over five growing seasons. 1998 Georgia Onion Research-Extension Report, Dept ECT, UGA-CAES Tifton Campus, Tifton, CREP 3-99:16-24.

Maw, B. W., Prussia, S. E., Hung, Y. C., Riley, D. G. and Batal, K., 2000a. Laser puff firmness evaluation of onions. 1999 Georgia Onion Research-Extension Report, Dept ECT, UGA-CAES Tifton Campus, Tifton, CREP 3-2000:38-41.

Maw, B. W., Prussia, S. E., Hung, Y. C., Riley, D. G., Batal, K. and Boyhan, G. E., 2001c. Laser puff firmness evaluation of onions. 2000 Georgia Onion Research-Extension Report, Dept ECT, UGACAES Tifton Campus, Tifton, CREP 3-2001:42-45.

Maw, B. W., Purvis, A. C. and Sumner, P. E., 1998a. Mechanically harvesting of sweet onions. Presented at the 1998 ASAE Annual International Meeting, July 12-16, Orlando, FL, Paper No. 98-1090 (11 p), St. Joseph, MI 49085.

Maw, B. W., Smittle, D. A., 1986. Undercutting onions. HortScience 21:432-434.

Maw, B. A., Smittle, D. A., 1988. Handling Vidalias with care. American Vegetable Grower 36(6):24,25,27.

Maw, B. W., Smittle, D. A. and Mullinix, B. G., 1997a. Artificially curing sweet onions. Applied Engineering in Agriculture 13:517-520.

Maw, B. W., Smittle, D. A. and Mullinix, B. G., 1997c. The influence of harvest maturity, curing and storage conditions upon the storability of sweet onions. Applied Engineering in Agriculture 13:511515.

Maw, B. W., Smittle, D. A., Mullinix, B. G. and Cundiff, J. S., 1998b. Design and evaluation of principles for mechanically harvesting sweet onions. Trans. ASAE 41:517-524.

Maw, B. W., Purvis, A. C. and Mullinix, B. G., 2001a. Enhancing the performance of the CPES sweet onion harvester. (In review)

Maw, B. W., Sumner, P. E., 1998. Guide to harvesting and curing of Vidalia onions. 1996-97 Georgia Onion Research-Extension Report, Dept ECT, UGA-CAES Tifton Campus, Tifton, CREP 3-98:19.

Maw, B., Sumner, P., 1999. Cooling Vidalia (sweet) onions. 1998 Georgia Onion Research-Extension Report, Dept ECT, UGA-CAES Tifton Campus, Tifton, CREP 3-99:29.

Maw, B. W., Sumner, P. E., 2000. Harvesting and curing Vidalia onions in plastic pallet bins. 1999 Georgia Onion Research-Extension Report, Dept ECT, UGA-CAES Tifton Campus, Tifton, CREP 32000:32-33.

Maw, B. W., Sumner, P. E. and Torrance, R. L., 1999a. Commercial mechanization for harvesting sweet onions. Presented at the 1999 Annual International Meeting (ASAE \& CSAE), July 18-21, Toronto, ON, Paper No. 99-1076 (12 p), St. Joseph, MI 49085.

Maw, B. W., Tollner, E. W. and Mullinix, B. G., 1997b. Factors influencing the curing of sweet onions. Presented at the 1997 ASAE Annual International Meeting, August 10-14, Minneapolis, MN, Paper No. 97-1021 (17 p), St. Joseph, MI 49085.

Maw, B. W., Tollner, E. W. and Mullinix, B. G., 1998c. Factors influencing the curing of sweet onions. 1996-1997 Georgia Onion Research-Extension Report, Dept ECT, UGA-CAES Tifton Campus, Tifton, CREP 3-98:26-31. 
Maw, B. W., Tollner, E. W., Smittle, D. A. and Hung, Y. C., 1993. Curing Vidalia onions. Presented at the 1993 International Summer Meeting (ASAE \& CSAE), June 20-23, Spokane, WA, Paper No. 931043 (8 p), St. Joseph, MI 49085.

Maw, B. W., Torrance, R. L. and Dales, D. H., 1998d. A comparison of the shelf life of Vidalia onions following harvest by hand and by machine. 1996-1997 Georgia Onion Research-Extension Report, Dept ECT, UGA-CAES Tifton Campus, Tifton, CREP 3-98:22-25.

Maw, B. W., Torrance, R. L. and Dales, D. H., 1999b. Comparison of the shelf life of Vidalia onions following harvest by [hand] and by machine. 1998 Georgia Onion Research-Extension Report, Dept ECT, UGA-CAES Tifton Campus, Tifton, CREP 3-99:25-28.

Maw, B. W., Torrance, R. L. and Mullinix, B. G., 2001b. Suitability of full bed elevator harvesters for sweet onions. (In review).

Maw, B. W., Torrance, R. L. and Welsh, C. C., 2000b. Comparison of the shelf life of Vidalia onions following harvest by hand and by machine.1999 Georgia Onion Research-Extension Report, Dept ECT, UGA-CAES Tifton Campus, Tifton, CREP 3-2000:34-37.

Maw, B. W., Williams, E. J. and Mullinix, B. G., 2000c. Resistance of sweet onions to airflow. 1999 Georgia Onion Research-Extension Report, Dept ECT, UGA-CAES Tifton Campus, Tifton, CREP 32000:26-31.

Mullinix, B. G., Maw, B. and Dales, D., 1999. Influence of storage conditions on the longevity of sweet onions in 1998. 1998 Georgia Onion Research-Extension Report, Dept ECT, UGA-CAES Tifton Campus, Tifton, CREP 3-99:30-37.

Mullinix, B., Lahue, S. and Maw, B., 1996a. Moisture loss (\%) during storage of individual onions as affected by harvest maturity, varying length of curing (hr), grade size, and level of humidity. HortScience 31:755. (Abs.)

Mullinix, B., Maw, B. and Lahue, S., 1996b. Percent onions lost during storage as affected by harvest maturity, varying length of curing (hr), grade size, and level of humidity. HortScience 31:755. (Abs.)

Mullinix, B., Maw, B. and Lahue, S., 1997. Modelling moisture loss of onions in storage using moisture loss information obtained from individually measured onions. HortScience 32:598. (Abs.)

Purvis, A. C., 1998. Influence of fertilization on pungency and shelf life of two onion cultivars. 1996-97 Georgia Onion Research-Extension Report, Dept ECT, UGA-CAES Tifton Campus, Tifton, CREP 398:34-37.

Purvis, A., 1999. Cultivar and nitrogen effects on seed-stem formation [bolting] in Vidalia onions. 1998 Georgia Onion Research-Extension Report, Dept ECT, UGA-CAES Tifton Campus, Tifton, CREP 399:41-42.

Purvis, A., Hakim, A., 1999a. Effect of bruising on weight loss and storage quality of two onion cultivars. 1998 Georgia Onion Research-Extension Report, Dept ECT, UGA-CAES Tifton Campus, Tifton, CREP 3-99:44-45.

Purvis, A., Hakim, A., 1999b. Effect of heat treatment to control Botrytis neck rot on the integrity of onion bulb scales. 1998 Georgia Onion Research-Extension Report, Dept ECT, UGA-CAES Tifton Campus, Tifton, CREP 3-99:46-47.

Purvis, A., Torrance, R., 1999. Using the instrumented sphere to assess damage of Vidalia onions during harvesting and handling. 1998 Georgia Onion Research-Extension Report, Dept ECT, UGA-CAES Tifton Campus, Tifton, CREP 3-99:43.

Randle, W. M., 1998. Field variation of bulb pungency. 1996-97 Georgia Onion Research-Extension Report, Dept ECT, UGA-CAES Tifton Campus, Tifton, CREP 3-98:38-40.

Shahin, M. A., Tollner, B., Gitaitis, R., Sumner, D. and Maw, B., 1999. Classification of onions based internal defects using image processing and neural network techniques. 1998 Georgia Onion Research-Extension Report, Dept ECT, UGA-CAES Tifton Campus, Tifton, CREP 3-99:63-64.

Smittle, D. A., 1983. Georgia onions: A sweet story. Georgia Young Farmer 8(2):8-9.

Smittle, D. A., 1984. Responses of onions to sulfur and nitrogen fertilization. UGA-CA-AES Research Report No. 455, pp. 1-10. 
Smittle, D. A., 1988. Evaluation of storage methods for 'Granex' onions. J Amer Soc Hort Sci 113:877880.

Smittle, D. A., 1989a. Controlled atmosphere storage of short-day onions. Proc. National Onion Research Conference, Boise, ID, December 7-8, pp 150-157.

Smittle, D. A., 1989b. Controlled atmosphere storage of Vidalia onions. Proc. Natl. Onion Res. Conf., pp 150-157.

Smittle, D. A., 1990. Cultural system and cultivar affect controlled atmosphere storage of short-day onions. Onion World 6(2):6-8,10.

Smittle, D. A., 1991a. Commercial storage of Vidalia onions. Onion World 7(2):10-12.

Smittle, D. A., 1991b. Vidalia onion CA storage requirements. Proc. National Onion Research Conference, pp. 74-76.

Smittle, D. A., 1991c. Susceptibility of onion to rooting during CA storage. Proc. National Onion Research Conference, pp. 67-73.

Smittle, D. A., 1992. Vidalia onions can be stored in apple CA facilities. Onion World 8(7):20-21,28-29.

Smittle, D. A., 1994. CA storage for Vidalia onions, 1993-94 results. 1993 Georgia Onion ResearchExtension Report, Dept RI, UGA-CAES Tifton Campus, Tifton, CREP 3-94:36-38.

Smittle, D. A., Hayes, M. J. and Dickens, W. L., 1979. Quality evaluation of onion. UGA-CA-AES Research Report No. 336, pp. 3-10.

Smittle, D. A., Maw, B. W., 1988. Effects of maturity and harvest methods on storage and quality of onions. HortScience 23:141-143.

Smittle, D. A., Williamson, R. E., 1978. Onion production and curing in Georgia. UGA-CA-CPES Research Report No. 284, pp 3-11.

Sumner, D., 1998. Diseases induced by fungi: Soil fumigation in direct seeded onion. 1996-97 Georgia Onion Research-Extension Report, Dept ECT, UGA-CAES Tifton Campus, Tifton, CREP 3-98:4547.

Sumner, D., 1999. Research on diseases induced by fungi. 1998 Georgia Onion Research-Extension Report, Dept ECT, UGA-CAES Tifton Campus, Tifton, CREP 3-99:58-62.

Sumner, D. R., 2000. Control of soilborne pathogens and bulb rot with soil fumigation in direct-seeded sweet onion, 1998-1999. 1999 Georgia Onion Research-Extension Report, Dept ECT, UGA-CAES Tifton Campus, Tifton, CREP 3-2000:48-52.

Sumner, D. R., Gay, J. D., 1995. Research on diseases induced by fungi: 1993-1994. 1994 Georgia Onion Research-Extension Report, Dept RI, UGA-CAES Tifton Campus, Tifton, CREP 3-95:47-56.

Sumner, D. R., Gitaitis, R. D., Gay, J. D., Smittle, D. A., Maw, B. W., Tollner, E. W. and Hung, Y. C., 1997. Control of soilborne pathogenic fungi in fields of sweet onion. Plant Disease 81:885-891.

Tollner, E. W., Hung, Y. C., Maw, B., Sumner, D. R. and Gitaitis, R. D., 1995. Nondestructive testing for identifying poor quality onions. 1994 Georgia Onion Research-Extension Report, Dept RI, UGACAES Tifton Campus, Tifton, CREP 3-95:57-73.

Tollner, E. W., Shahin, M. A., 1998. Detecting internal defects in onions using x-ray imaging and computer vision. 1996-1997 Georgia Onion Research-Extension Report, Dept ECT, UGA-CAES Tifton Campus, Tifton, CREP 3-98:48-49.

Tollner, E. W., Shahin, M. A., 2000. X-ray imaging for classifying food products based on internal defects. 1999 Georgia Onion Research-Extension Report, Dept ECT, UGA-CAES Tifton Campus, Tifton, CREP 3-2000:53-54.

Vavrina, C. S., Smittle, D. A., 1993. Evaluating sweet onion cultivars for sugar concentrations and pungency. HortScience 28:804-806. 
Figure 1. Effect of cultivar ('Equanex' and 'Pegasus') and harvest method ( $\mathrm{HH}=$ hand harvest, MU=machine, untopped, and MT=machine, topped) on storage longevity measured by percent good onions remaining in 1997.

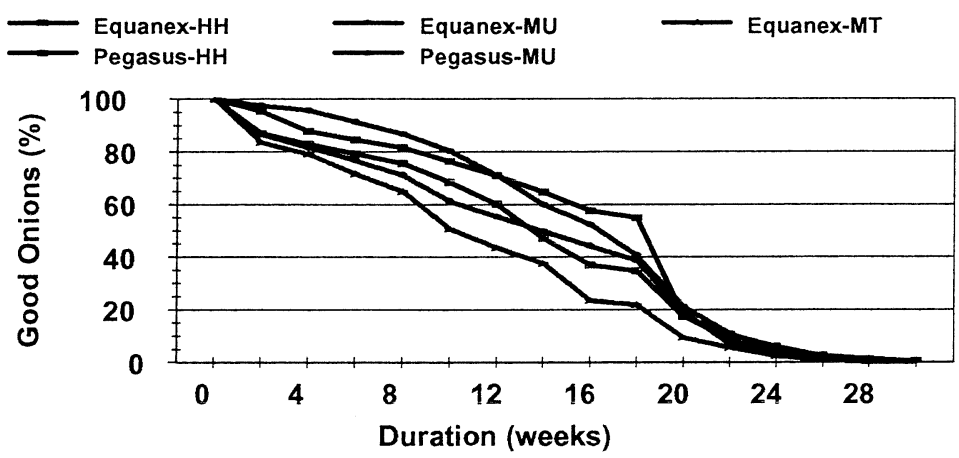

Figure 2. Effect of cultivar ('Savannah Sweet' and 'Vidalia Sweet') and harvest method ( $\mathrm{HH}=$ hand harvest, $\mathrm{MU}=$ machine, untopped, and $\mathrm{MT}=$ machine, topped) on storage longevity measured by percent good onions remaining in 1998.

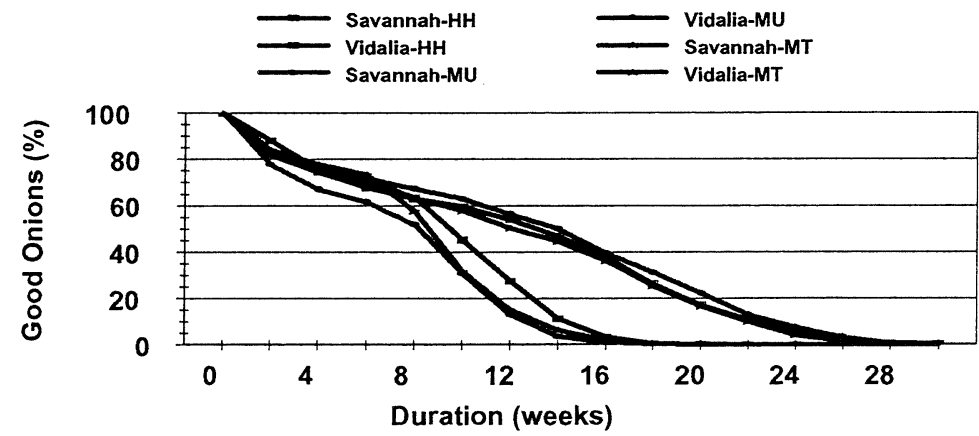

Figure 3. Effect of cultivar ('Nikita' and 'Vidalia Sweet') and harvest method (HH=hand harvest, $\mathrm{MU}=$ machine, untopped, and $\mathrm{MT}=$ machine, topped) on storage longevity measured by percent good onions remaining in 1999 .

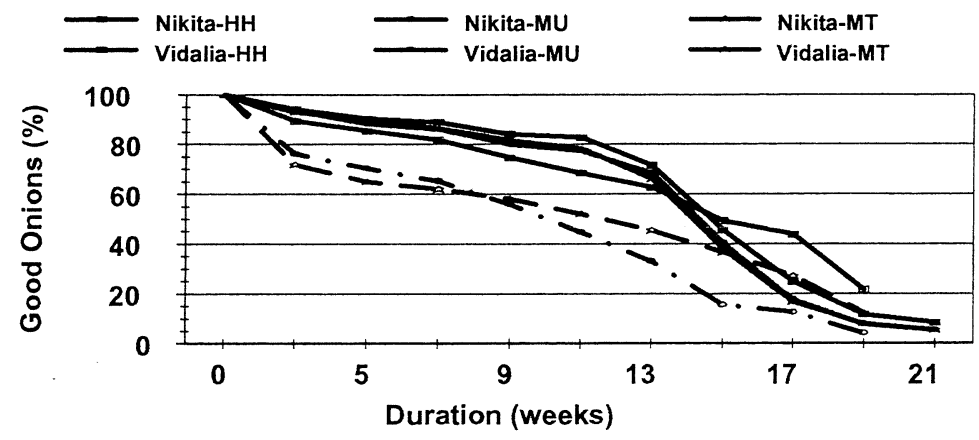


Figure 4. Effect of duration of curing, depth of curing, and harvest maturity interacting with storage environment on storage

A

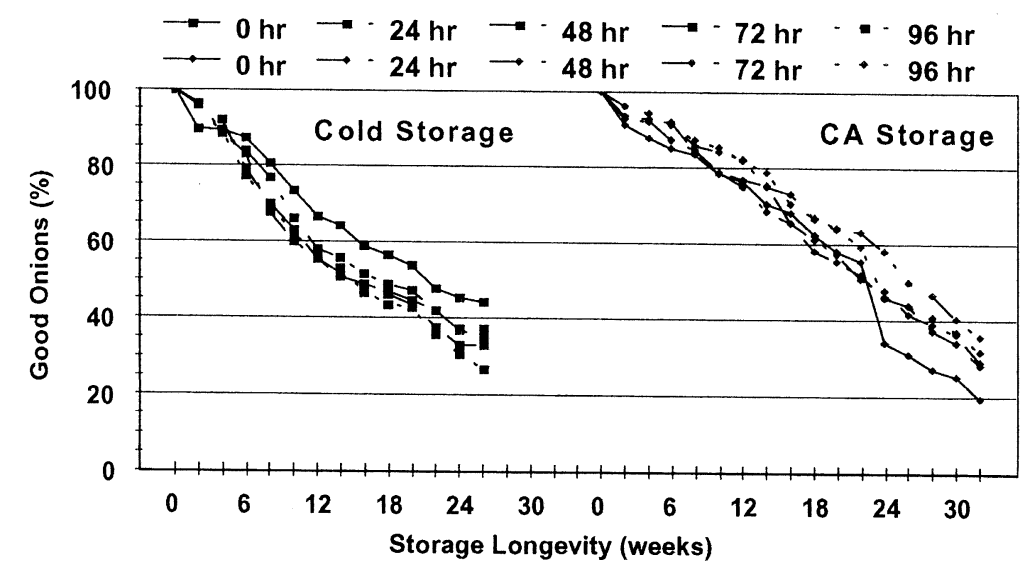

C

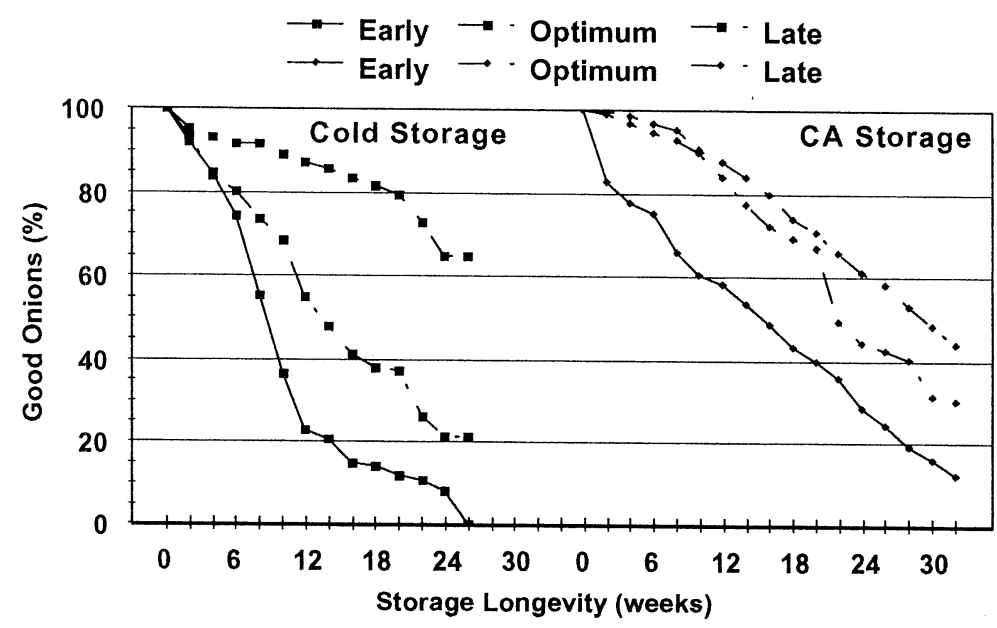

B

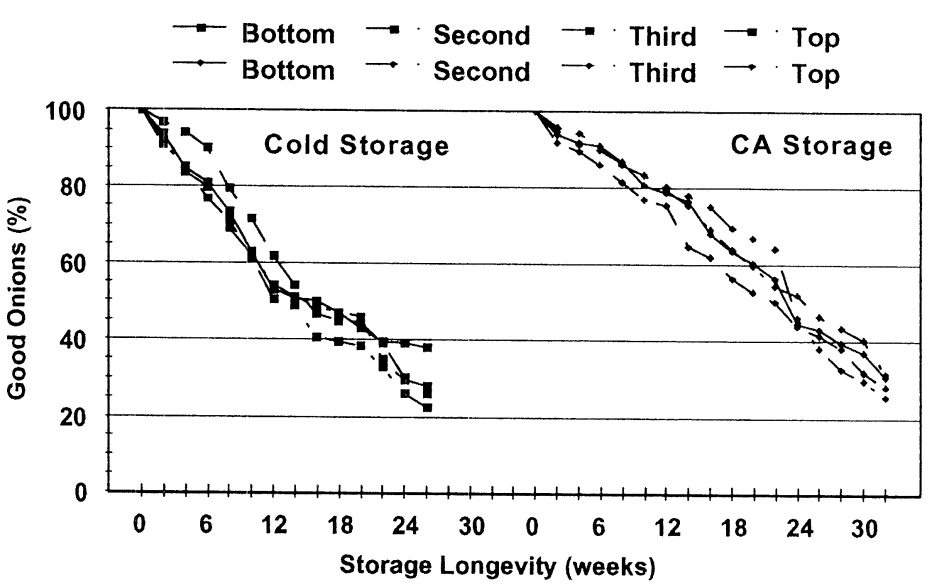

D Test of Fixed Effects for Jumbo Grade Onions

Effect

Harvest Maturity $(\mathrm{H})$

Num Den

Hours of Curing (C)

Cure Depth (D)

Environment (E)

Storage Time (S)

$E^{*} C^{*} S$

$E^{*} D^{*} S$

$E^{*} H^{*} S$

$\begin{array}{rr}\text { df } & \text { df } \\ 2 & 1700 \\ 4 & 1700 \\ 3 & 1700 \\ 1 & 1700 \\ 16 & 1700 \\ 132 & 1700 \\ 99 & 1700 \\ 66 & 1700\end{array}$

F Value $\quad \mathrm{Pr}>\mathrm{F}$

$821.390 .0001^{* *}$

13.220 .0001 **

$1.710 .1630 \mathrm{~ns}$

374.910 .0001 **

381.170 .0001 **

$0.760 .9778 \mathrm{~ns}$

$\begin{array}{ll}1.02 & 0.4394 \mathrm{~ns}\end{array}$

$12.450 .0001^{\text {** }}$

\section{Cov Parm}

Residual

\section{SE \\ 7.96}

$\begin{array}{rr}Z & P r>Z \\ 29.15 & 0.0001\end{array}$


Figure 5. Effect of duration of curing, depth of curing, and harvest maturity interacting with storage environment on storage longevity of large grade onions with accompanying anova table $(\mathrm{CA}=$ controlled atmosphere).

A

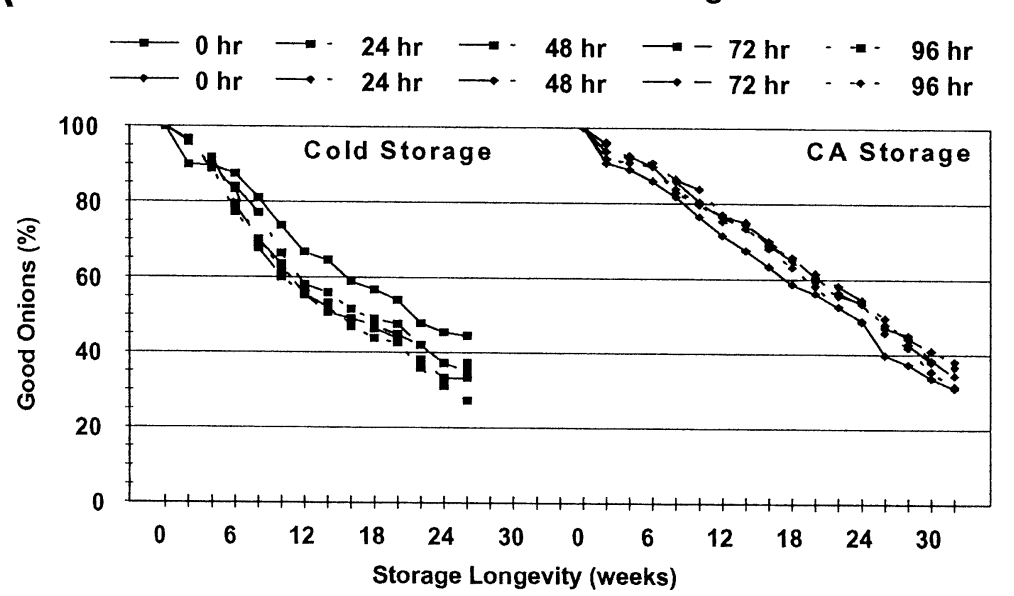

C

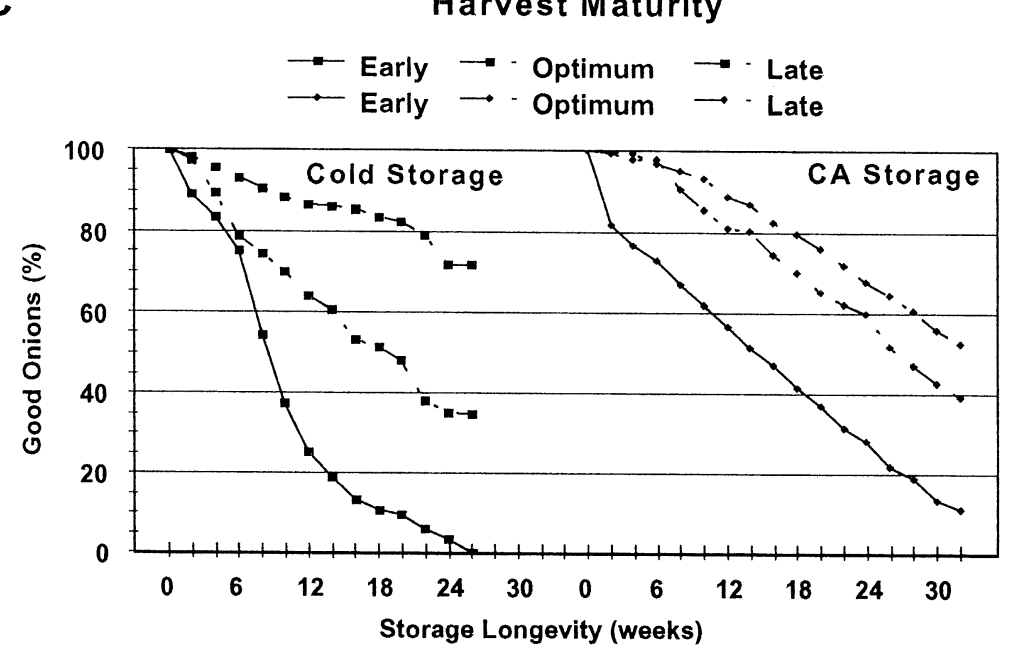

B
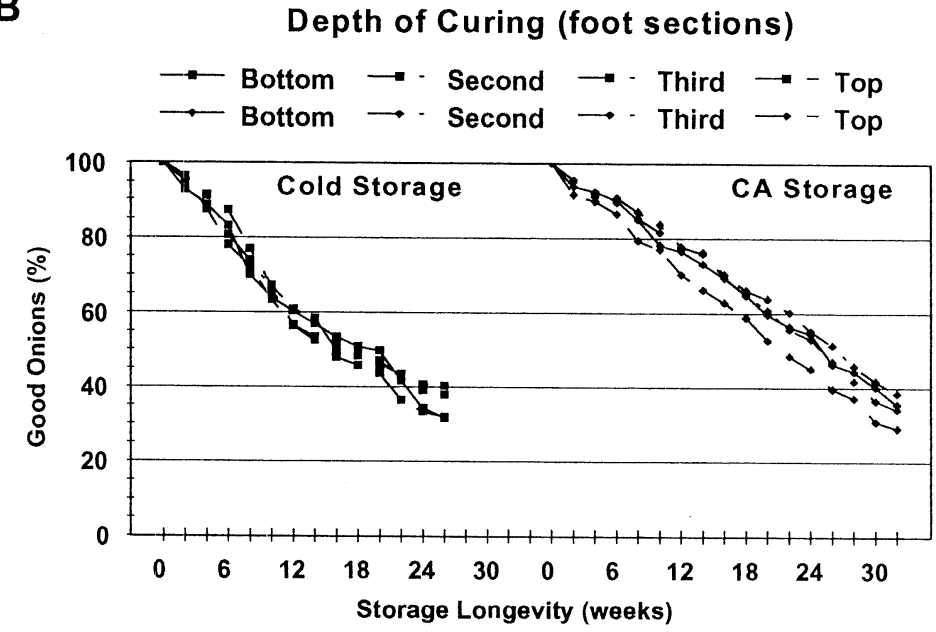

D Test of Fixed Effects for Large Grade Onions

$\begin{array}{lrrrr} & \text { Num } & \text { Den } & & \\ \text { Effect } & \text { df } & \text { df } & \text { F Value } & \text { Pr }>\text { F } \\ \text { Harvest Maturity (H) } & 2 & 1700 & 1343.38 & 0.0001^{* *} \\ \text { Hours of Curing (C) } & 4 & 1700 & 2.88 & 0.0001^{*} \\ \text { Cure Depth (D) } & 3 & 1700 & 17.21 & 0.0001^{* *} \\ \text { Environment (E) } & 1 & 1700 & 369.78 & 0.0001^{* *} \\ \text { Storage Time (S) } & 16 & 1700 & 441.78 & 0.0001^{* *} \\ E^{*} C^{*} S & 132 & 1700 & 0.74 & 0.9853 \text { ns } \\ E^{*} D^{*} S & 99 & 1700 & 0.36 & 1.0000 \text { ns } \\ E^{*} H^{\star} S & 66 & 1700 & 15.10 & 0.0001^{* *}\end{array}$

$\begin{array}{lrrrr}\text { Cov Parm } & \text { Estimate } & \text { SE } & \mathrm{Z} & \mathrm{Pr}>\mathrm{Z} \\ \text { Residual } & 183.79 & 6.30 & 29.15 & 0.0001\end{array}$


Figure 6. Effect of duration of curing, depth of curing, and harvest maturity interacting with storage environment on storage longevity of medium grade onions with accompanying anova table $(\mathrm{CA}=$ controlled atmosphere $)$.

A

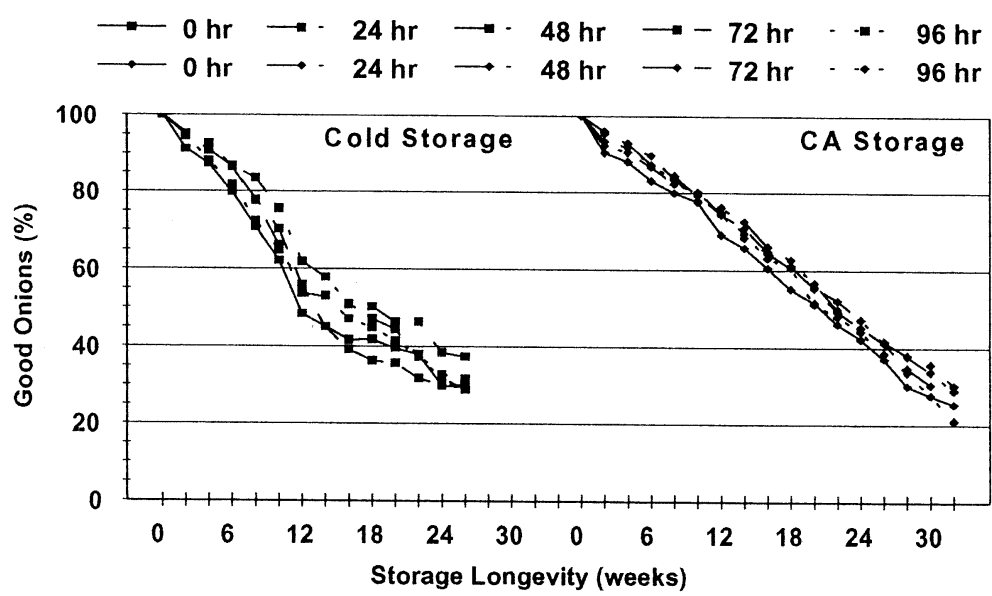

C

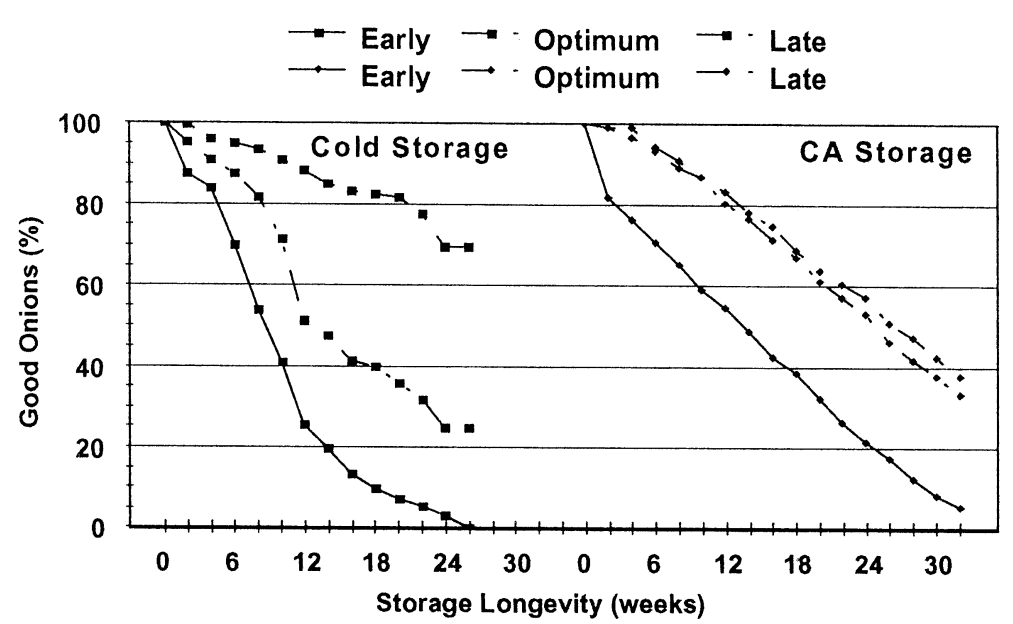

B
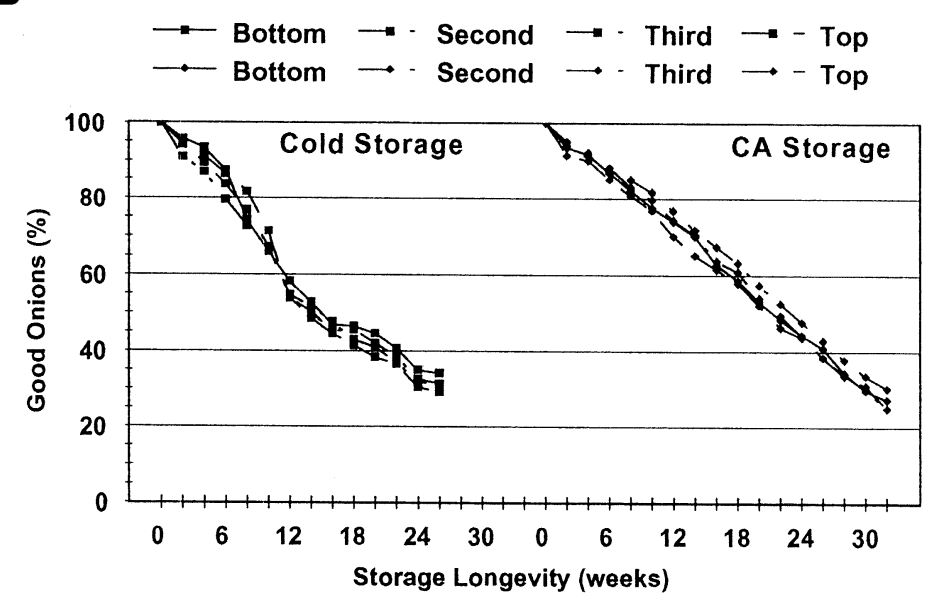

D Test of Fixed Effects for Medium Grade Onions

$\begin{array}{lrrrr} & \text { Num } & \text { Den } & \\ \text { Effect } & \text { df } & \text { df } & \text { F Value } & \text { Pr }>\text { F } \\ \text { Harvest Maturity (H) } & 2 & 1700 & 1314.01 & 0.0001 * * \\ \text { Hours of Curing (C) } & 4 & 1700 & 9.80 & 0.0001^{* *} \\ \text { Cure Depth (D) } & 3 & 1700 & 1.80 & 0.1445 \text { ns } \\ \text { Environment (E) } & 1 & 1700 & 225.70 & 0.0001^{* *} \\ \text { Storage Time (S) } & 16 & 1700 & 508.55 & 0.0001 * * \\ E^{*} C^{*} S & 132 & 1700 & 0.45 & 1.0000 \text { ns } \\ E^{*} D^{*} S & 99 & 1700 & 0.34 & 1.0000 \text { ns } \\ E^{*} H^{*} S & 66 & 1700 & 15.79 & 0.0001^{* *}\end{array}$

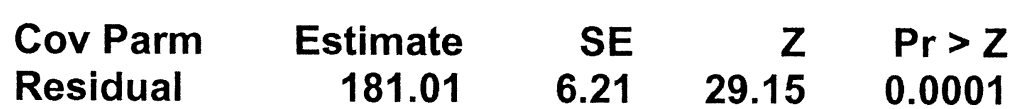


Figure 7. Effect of duration of curing, depth of curing, and harvest maturity interacting with storage environment on storage longevity of small grade onions with accompanying anova table $(\mathrm{CA}=$ controlled atmosphere).

A

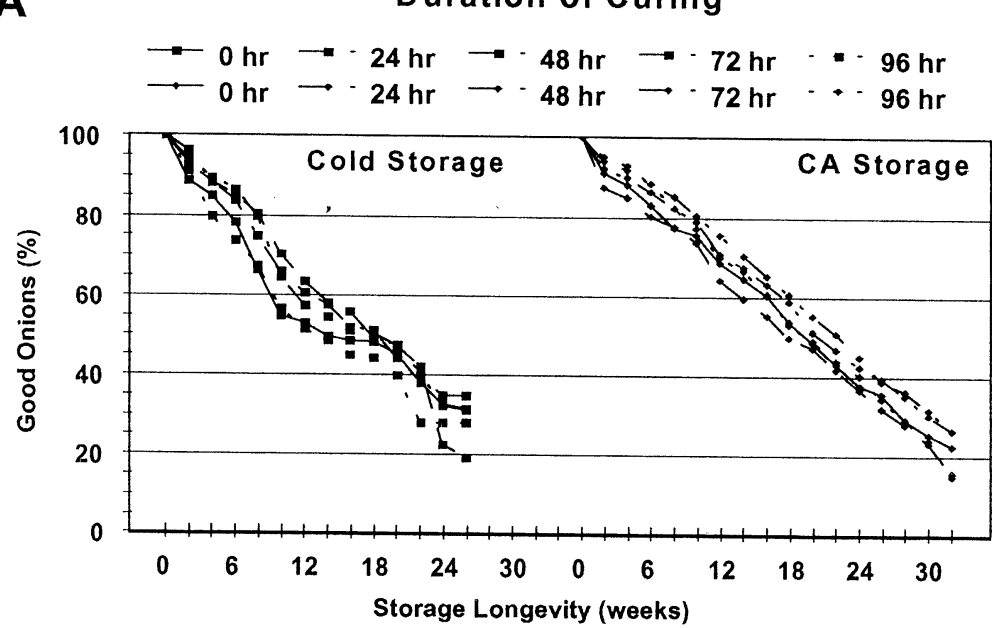

C

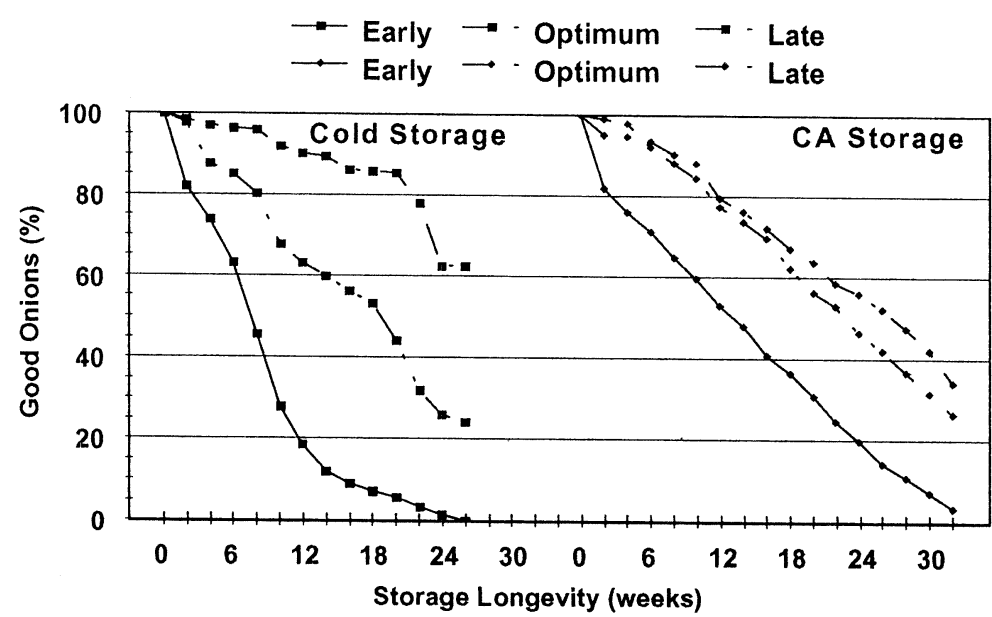

B

Depth of Curing (foot sections)

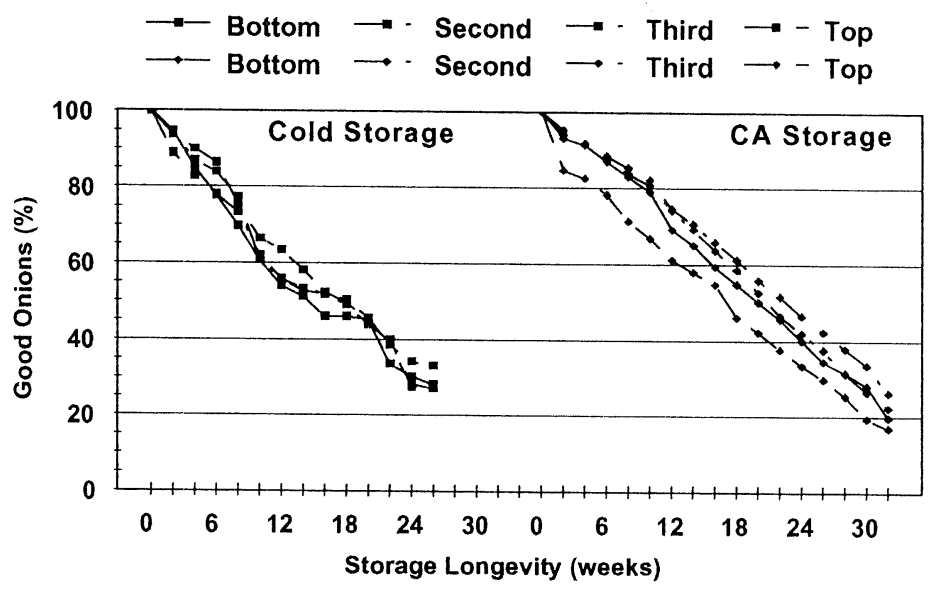

D Test of Fixed Effects for Small Grade Onions

$\begin{array}{lrrrr}\text { Effect } & \text { Num } & \text { Den } & & \\ \text { Harvest Maturity (H) } & \text { df } & \text { df } & \text { F Value } & \text { Pr }>\text { F } \\ \text { Hours of Curing (C) } & 4 & 1700 & 1215.51 & 0.0001^{* *} \\ \text { Cure Depth (D) } & 3 & 1700 & 12.06 & 0.0001^{* *} \\ \text { Environment (E) } & 1 & 1700 & 83.16 & 0.0001^{* *} \\ \text { Storage Time (S) } & 16 & 1700 & 463.08 & 0.0001^{* *} \\ E^{*} C^{*} S & 132 & 1700 & 0.65 & 0.9990 \text { ns } \\ E^{*} D^{*} S & 99 & 1700 & 0.34 & 0.4849^{\text {ns }} \\ E^{*} H^{*} S & 66 & 1700 & 15.68 & 0.0001^{* *}\end{array}$

$\begin{array}{lrrrr}\text { Cov Parm } & \text { Estimate } & \text { SE } & Z & \text { Pr }>Z \\ \text { Residual } & 201.16 & 6.90 & 29.15 & 0.0001\end{array}$ 
Figure 8. Effect of duration of curing, depth of curing, and harvest maturity interacting with storage environment on storage

A

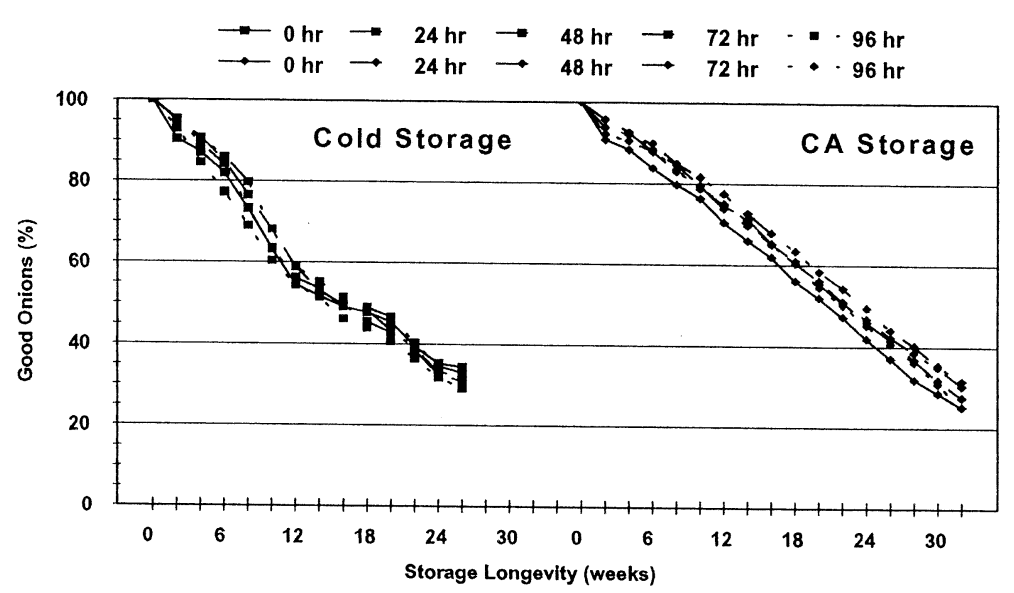

C

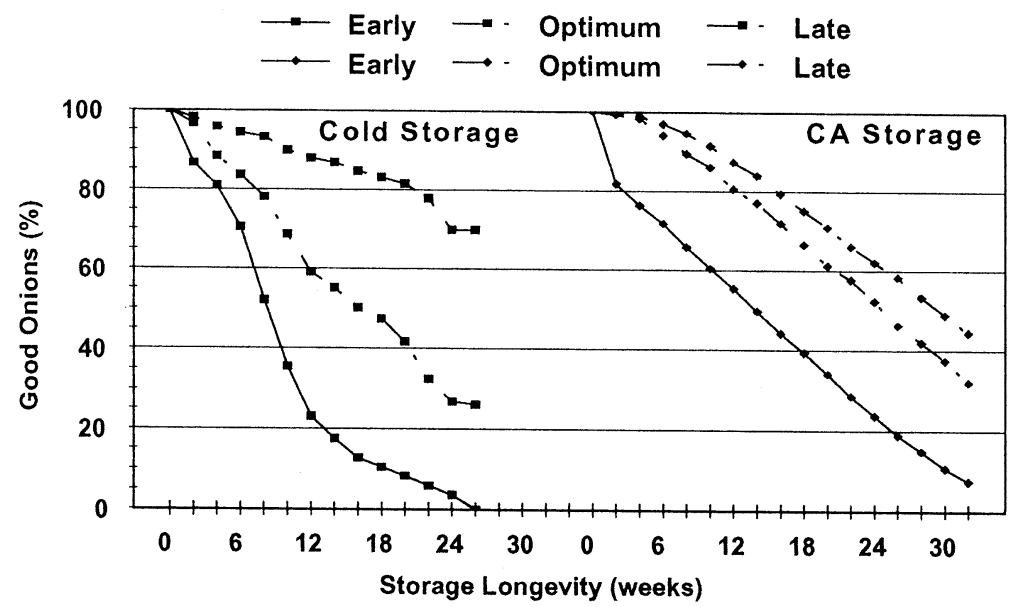

B

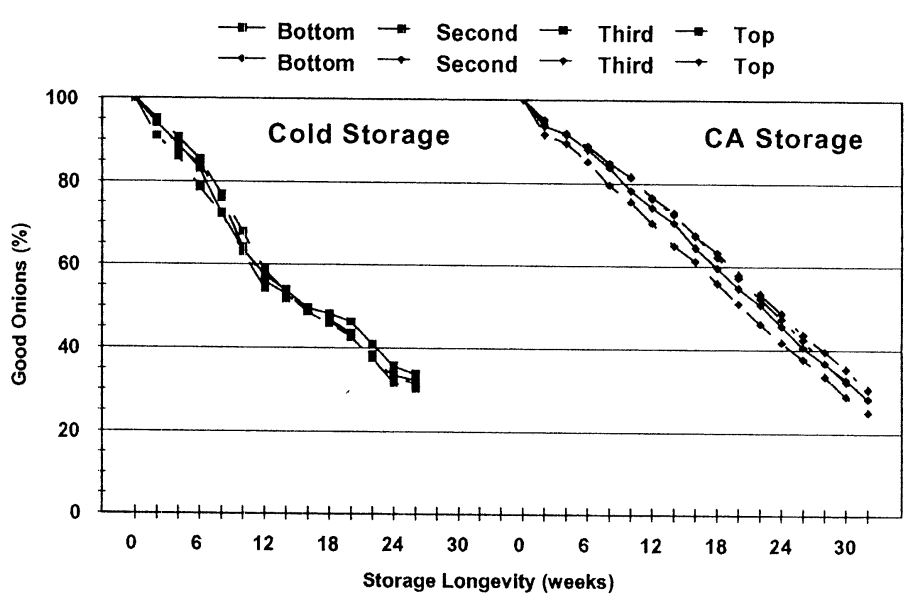

D Test of Fixed Effects for Mixed Grade Onions

$\begin{array}{lrrrr} & \text { Num } & \text { Den } & \\ \text { Effect } & \text { df } & \text { df } & \text { F Value } & \text { Pr }>\text { F } \\ \text { Harvest Maturity (H) } & 2 & 1700 & 2453.35 & 0.0001^{* *} \\ \text { Hours of Curing (C) } & 4 & 1700 & 10.94 & 0.0001^{* *} \\ \text { Cure Depth (D) } & 3 & 1700 & 6.50 & 0.0002^{* *} \\ \text { Environment (E) } & 1 & 1700 & 469.96 & 0.0001^{* *} \\ \text { Storage Time (S) } & 16 & 1700 & 899.53 & 0.0001^{* *} \\ E^{*} C^{*} S & 132 & 1700 & 0.35 & 1.0000 \text { ns } \\ E^{*} D^{*} S & 99 & 1700 & 0.56 & 0.9998 \text { ns } \\ E^{*} H^{*} S & 66 & 1700 & 28.20 & 0.0001^{* *}\end{array}$

\begin{tabular}{|c|c|c|c|}
\hline $\begin{array}{l}\text { Cov Parm } \\
\text { Residual }\end{array}$ & $\begin{array}{r}\text { Estimate } \\
98,30\end{array}$ & $\begin{array}{r}\text { SE } \\
3.37\end{array}$ & $\begin{array}{r}Z \\
29.15\end{array}$ \\
\hline
\end{tabular}


Figure 9. Predicted Percentage Good Onions Remaining during Storage for 30 weeks as Affected by Harvest Maturity for Jumbo, Large, Medium, Small, and Mixed Grades Averaged over the Years, 1992-1998, and ANOVA from Proc MIXED.
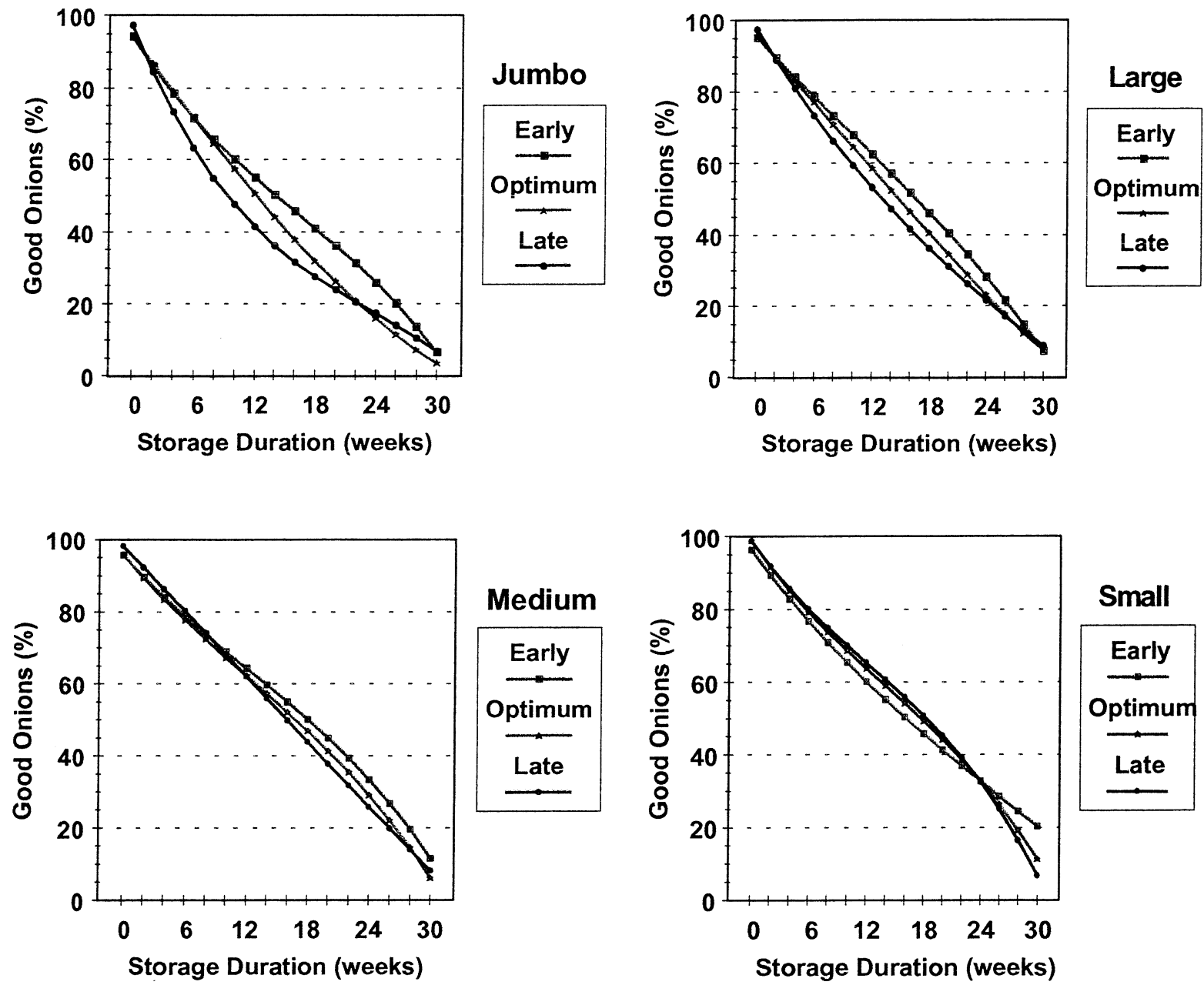

\begin{tabular}{c|c|c|c} 
Random Effect & df & Cov Parm Est & Z test \\
\hline Year $(Y)$ & 6 & 331.12 & $1.66^{\star}$ \\
\hline$Y^{\star} M^{\star} W$ & 282 & 267.99 & $11.44^{\star \star}$ \\
\hline$Y^{\star} G$ & 18 & 30.79 & $2.92^{\star \star}$ \\
\hline Residual & 936 & 40.49 & $20.57^{\star \star}$ \\
\hline Fixed Effect & ndf,ddf & F test & Pr $>$ F \\
\hline Maturity (M) & 2,282 & 1.55 & 0.2142 \\
\hline Weeks (W) & 15,45 & 18.50 & 0.0001 \\
\hline$M^{\star} W$ & 30,282 & 0.10 & 0.9999 \\
\hline Grade $^{*}$ & 3,18 & 5.35 & 0.0082 \\
\hline$M^{\star} G$ & 6,936 & 11.93 & 0.0001 \\
\hline$W^{\star} G$ & 45,936 & 2.98 & 0.0001
\end{tabular}

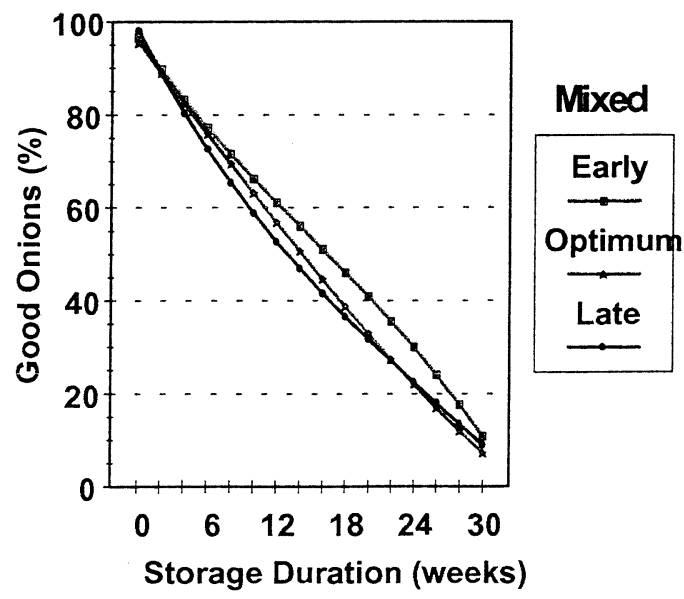


Figure 10. Predicted Percentage Good Onions Remaining during Storage for 30 weeks as Affected by Duration of Curing for Jumbo, Large, Medium, Small, and Mixed Grades Averaged over the Years, 1992-1998, and ANOVA from Proc MIXED.

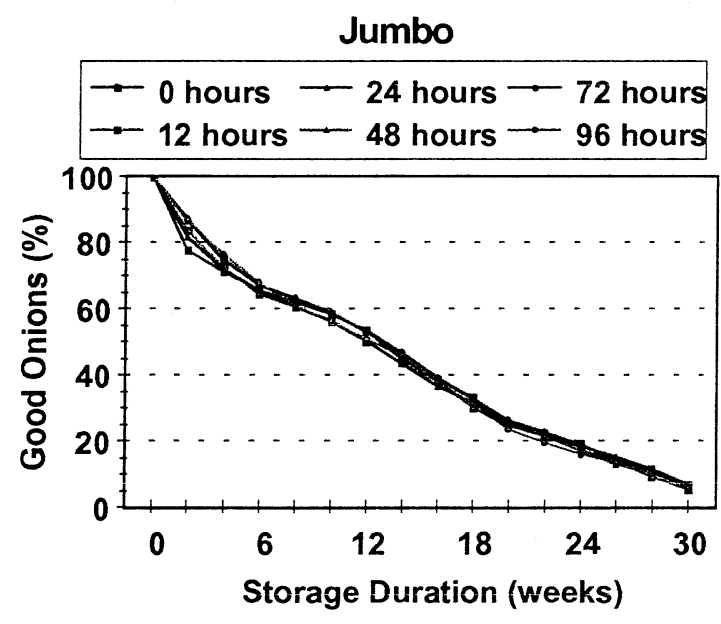

Medium

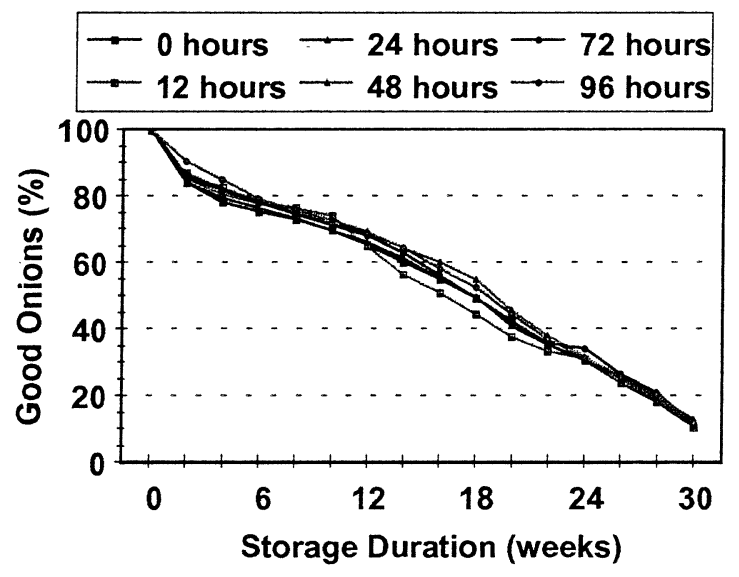

\begin{tabular}{c|c|c|c} 
Random Effect & df & Cov Parm Est & Z test \\
\hline Year (Y) & 6 & 375.83 & $1.68^{\star}$ \\
\hline$Y^{\star} C^{\star} W$ & 378 & 147.15 & $11.19^{\star \star}$ \\
\hline$Y^{\star} G$ & 18 & 39.82 & $2.97^{\star \star}$ \\
\hline Residual & 1359 & 24.06 & $23.81^{\star \star}$ \\
\hline Fixed Effect & ndf,ddf & F test & Pr $>$ F \\
\hline Cure Time (C) & 5,378 & 0.61 & 0.6920 \\
\hline Weeks (W) & 15,45 & 17.68 & 0.0001 \\
\hline C W & 75,378 & 0.55 & 0.9990 \\
\hline Grade & 3,18 & 5.44 & 0.0077 \\
\hline$C^{\star} G$ & 15,1359 & 1.43 & 0.1242 \\
\hline$W^{\star} G$ & 45,1359 & 5.91 & 0.0001
\end{tabular}

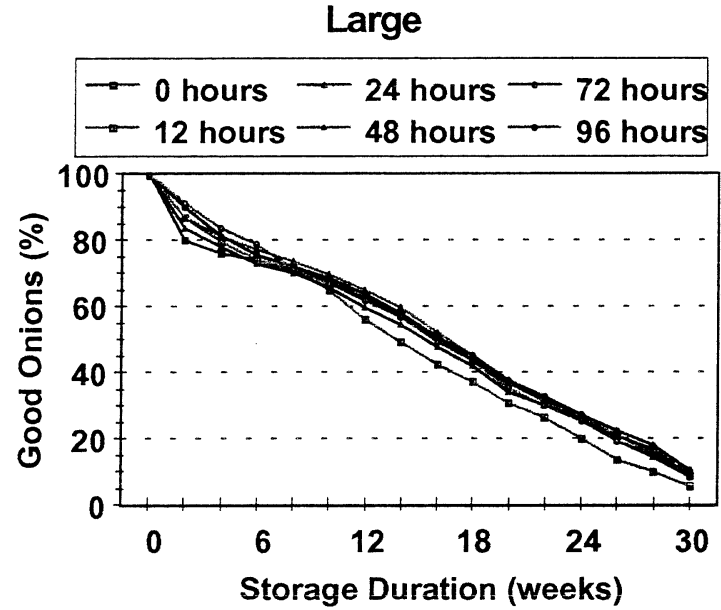

Small

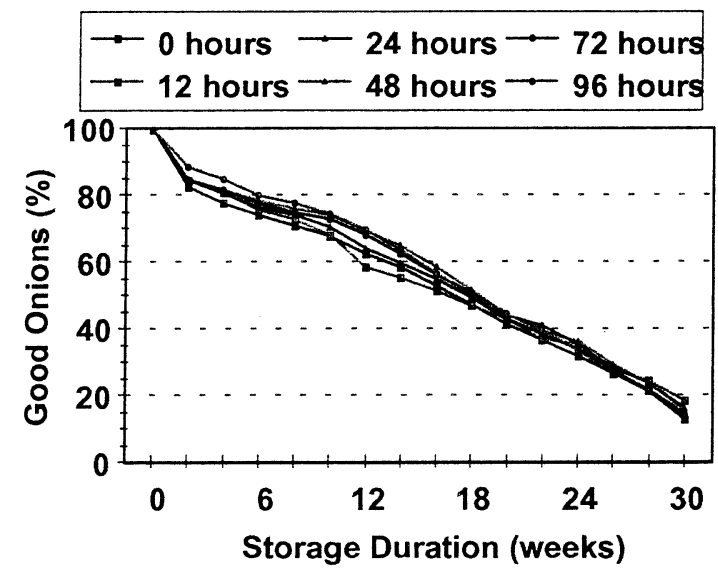

Mixed

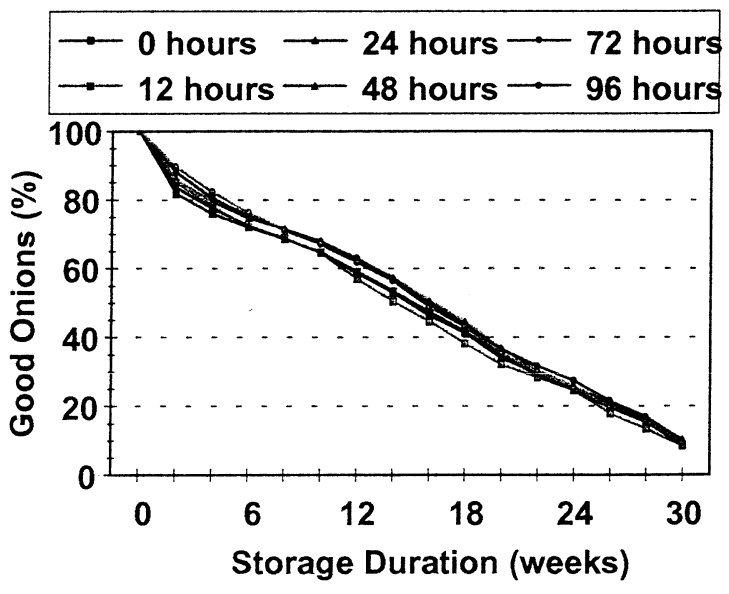


Figure 11. Predicted Percentage Good Onions Remaining during Storage for 30 weeks as Affected by Storage Environment for Jumbo, Large, Medium, Small, and Mixed Grades Averaged over the Years, 1992-1998, and ANOVA from Proc MIXED.
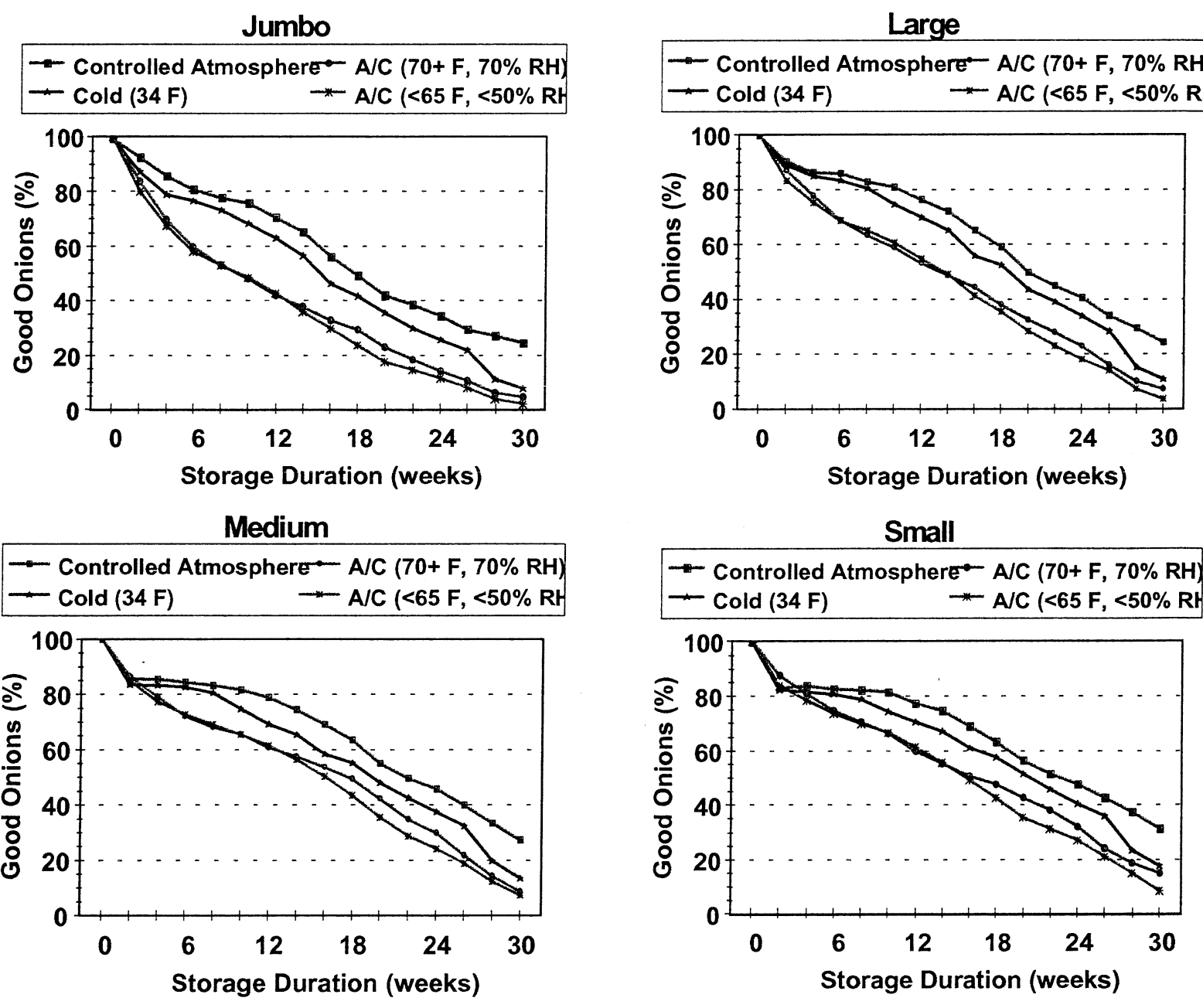

\begin{tabular}{c|c|c|c} 
Random Effect & df & Cov Parm Est & Z test \\
\hline Year (Y) & 6 & 464.36 & $1.68^{*}$ \\
\hline$Y^{\star} E^{\star} W$ & 218 & 276.21 & $10.21^{\star *}$ \\
\hline$Y^{\star} G$ & 18 & 34.48 & $2.92^{\star *}$ \\
\hline Residual & 789 & 23.06 & $18.08^{\star *}$ \\
\hline Fixed Effect & ndf,ddf & F test & Pr $>$ F \\
\hline Environment (E) & 3,9 & 2.58 & 0.1500 \\
\hline Weeks (W) & 15,45 & 7.27 & 0.0001 \\
\hline E*W & 45,218 & 0.18 & 0.9999 \\
\hline Grade & 3,18 & 4.51 & 0.0157 \\
\hline$E^{\star} G$ & 9,789 & 5.24 & 0.0001 \\
\hline$W^{\star} G$ & 45,789 & 5.20 & 0.0001
\end{tabular}

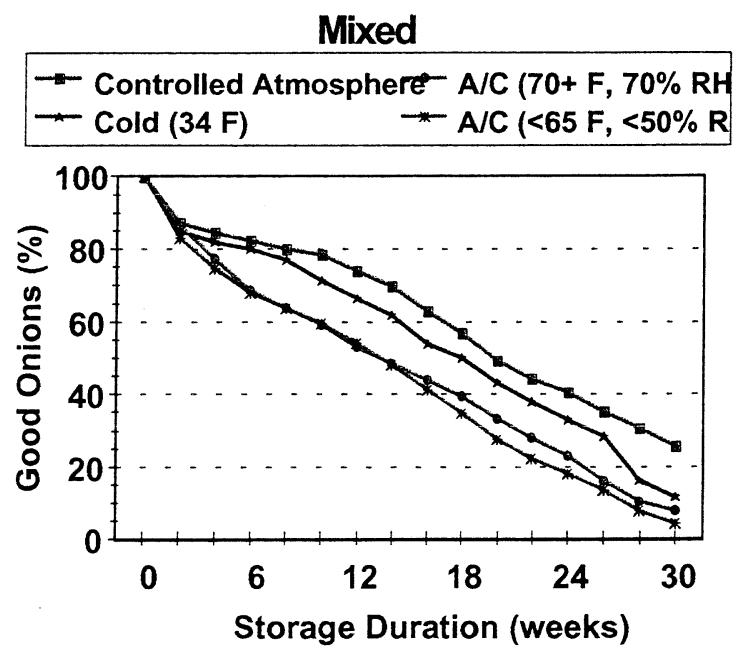


Figure 12. Distribution of Individually Measured Jumbo Before Curing and After Selected Hours of Curing Compared with Large Onions Before Curing (1994-1998).

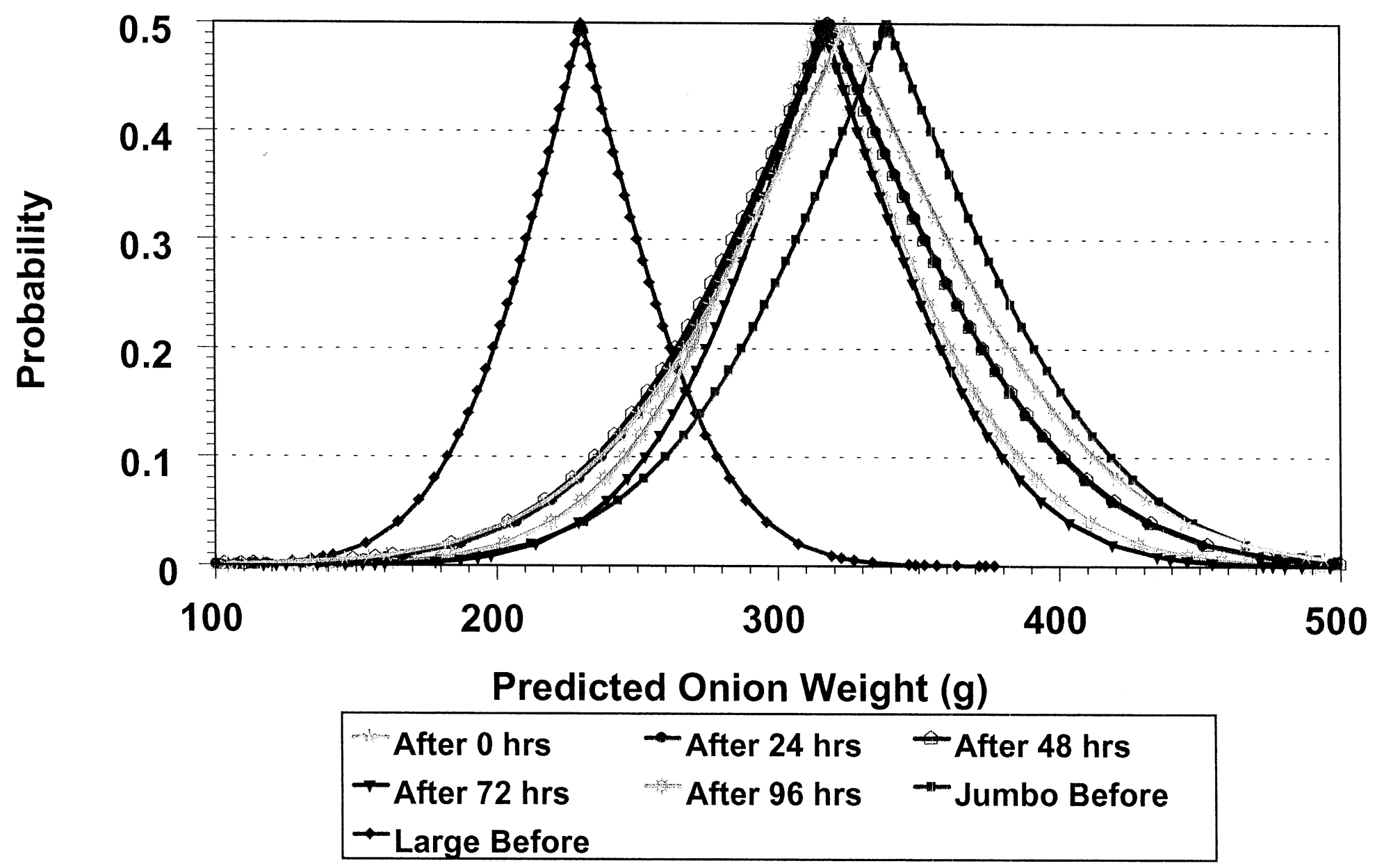


Figure 13. Distribution of Individually Measured Large Before Curing and After Selected Hours of Curing Compared with Medium Onions Before Curing (1994-1998).

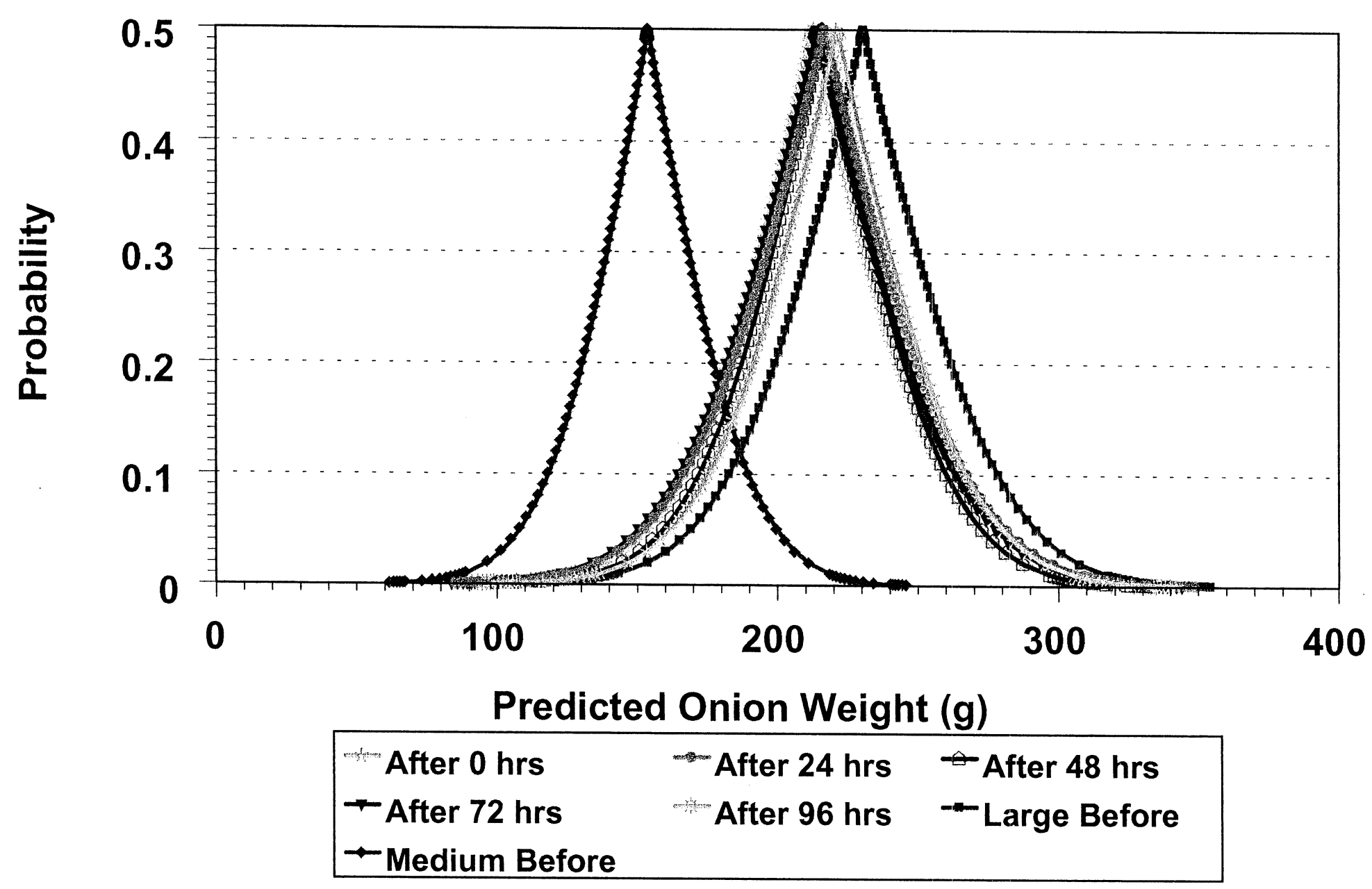


Figure 14. Distribution of Individually Measured Medium Before Curing and After Selected Hours of Curing Compared with Small Onions Before Curing (1994-1998).

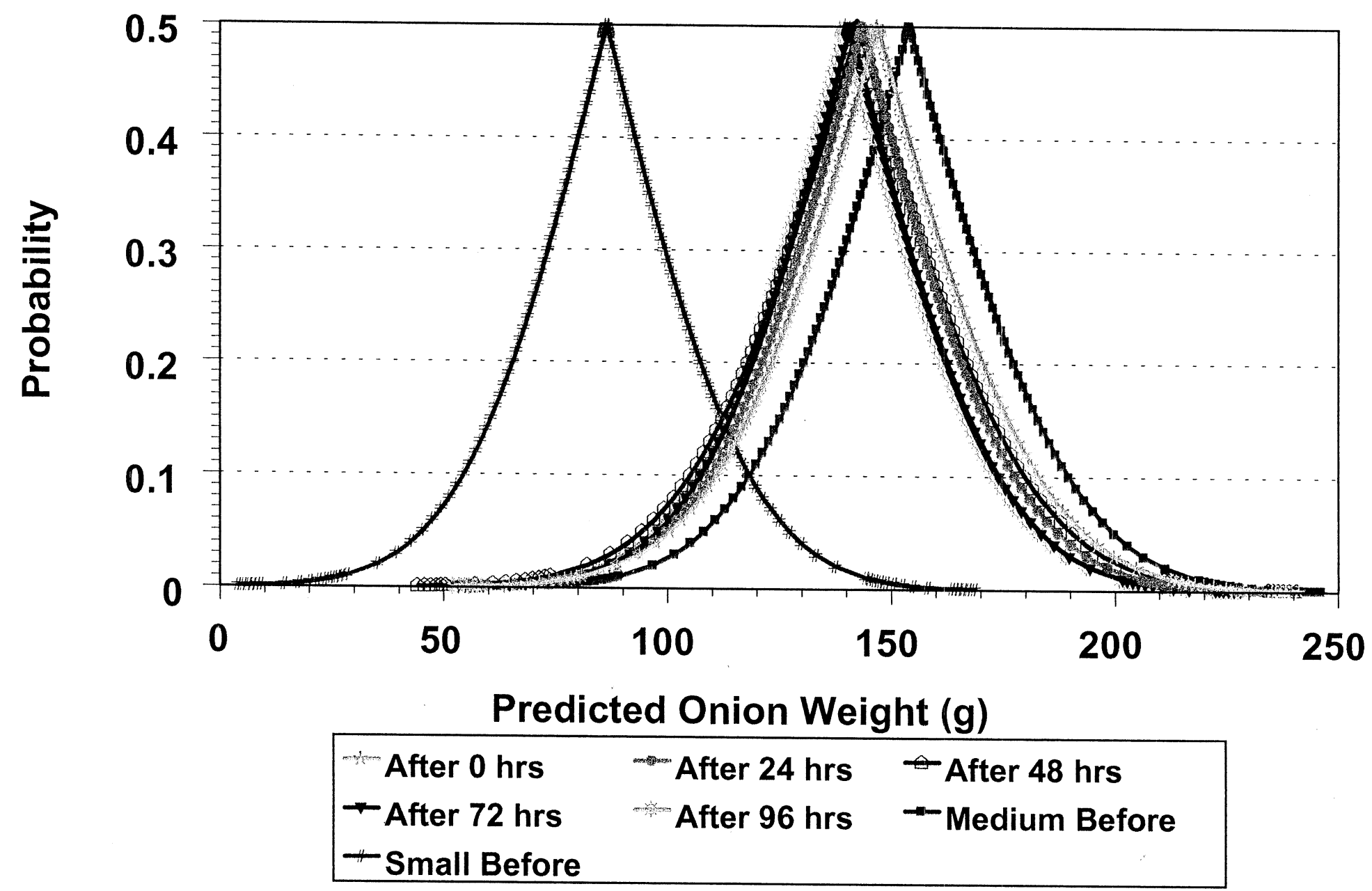

